\title{
Indole-3-carbinol induces cMYC and IAP-family downmodulation and promotes apoptosis of Epstein-Barr virus (EBV)-positive but not of EBV-negative Burkitt's lymphoma cell lines
}

\author{
Gema Perez-Chacon ${ }^{1}$, Cristobal de los Rios ${ }^{2,3}$ and Juan M. Zapata ${ }^{1}$ \\ ${ }^{1}$ Instituto de Investigaciones Biomedicas “Alberto Sols”, CSIC/UAM, ${ }^{2}$ \\ Instituto Teofilo Hernando and ${ }^{3}$ Departamento de Farmacologia y Terapeutica, \\ Facultad de Medicina, UAM, 28029 Madrid, Spain
}

Running title: $\mathrm{I} 3 \mathrm{C}$ induces apoptosis in $\mathrm{EBV}$-positive $\mathrm{BL}$

Corresponding authors: Juan M. Zapata (jmzapata@iiib.uam.es) and Gema Perez-Chacon (gpchacon@iib.uam.es). Instituto de Investigaciones Biomedicas "Alberto Sols", CSIC/UAM, Madrid 28029, Spain. Phone 34-914977032; Fax 34-915854401

\begin{abstract}
ABBREVIATIONS
ATM, ataxia telangiectasia mutated; ATR, ataxia telangiectasia and Rad3-related; BCL, B cell lymphoma; BIR, baculovirus IAP repeat; BL, Burkitt's lymphoma; CFLAR, CASP8 and FADD-like apoptosis regulator; cFLIP, Fas-associated death domain protein-like interleukin-1 $\beta$-converting enzyme inhibitory protein; cIAP, cellular inhibitor of apoptosis; DIM, 3,3'-diindolylmethane; EBV, Epstein-Barr virus; EBNA, Epstein-Barr virus nuclear antigen; I3C, indole-3-carbinol; LCL, lymphoblastoid cell line; LMP, Epstein-Barr virus latent membrane protein; NOD, non-obese diabetic; PARP, poly(ADP-ribose) polymerase; SCID, severe combined immunodeficiency; TCL, T cell lymphoma; XIAP, X-linked inhibitor of apoptosis.
\end{abstract}




\section{ABSTRACT}

Indole-3-carbinol (I3C) is a natural product found in broadly consumed plants of the Brassica genus, such as broccoli, cabbage, and cauliflower, which exhibits anti-tumor effects through poorly defined mechanisms. I3C can be orally administered and clinical trials have demonstrated that $\mathrm{I} 3 \mathrm{C}$ and derivatives are safe in humans. In this study we show that I3C efficiently induces apoptosis in cell lines derived from EBV-positive Burkitt's lymphomas (virus latency I/II), while it does not have any cytotoxic activity against EBVnegative Burkitt's lymphomas and immortalized EBV-infected lymphoblastoid cell lines (virus latency III). The effect of I3C in EBV-positive Burkitt's lymphoma is very specific, since only I3C and its C6-methylated derivative, but not other 3-substituted indoles, have an effect on cell viability. I3C treatment caused apoptosis characterized by loss of mitochondria membrane potential and caspase activation. I3C alters the expression of proteins involved in the control of apoptosis and transcription regulation in EBV-positive Burkitt's lymphoma cell lines. Among those, cMYC, cIAP1/2 and XIAP downmodulation at mRNA and protein level precede apoptosis induction, thus suggesting a role in I3C cytotoxicity. We also showed that I3C and, more particularly, its condensation dimer 3,3'-diindolylmethane (DIM) prolonged survival and reduced tumor burden of mice xenotransplanted with EBVpositive Burkitt's lymphoma Daudi cells.

In summary these results, together with previous reports from clinical trials indicating the lack of toxicity in humans of $\mathrm{I} 3 \mathrm{C}$ and derivatives, support the use of these compounds as a new therapeutic approach for treating patients with endemic (EBV-positive) Burkitt's lymphoma. 
Keywords: Indole-3-carbinol; 3,3'-diindolylmethane; Epstein-Barr virus; Burkitt's lymphoma; cMYC; cIAP; XIAP.

Chemicals: Indole-3-carbinol, PubChem CID 3712; (6-Methyl-1H-indol-3-yl)methanol, PubChem CID 22062103; 3,3'-diindolylmethane, PubChem CID 3071. 


\section{BACKGROUND}

Indole-3-carbinol (I3C) is a glucobrassicine derivative that is found in plants of the Cruciferae family, particularly in members of the Brassica genus, such as broccoli, cabbage, and cauliflower. $\mathrm{I} 3 \mathrm{C}$ is an orally bioactive compound that is formed by the hydrolysis of glucosinolate by the plant enzyme myrosinase [1]. Several studies have described the activity of $\mathrm{I} 3 \mathrm{C}$ and both natural and synthetic derivatives as chemopreventive and anti-tumor agents, regulating processes such as inflammation, cell proliferation, and tumor invasion [24]. Indeed, I3C has been shown to inhibit proliferation and induce apoptosis of a variety of tumors and cell lines of breast, endometrium, prostate, and colon cancer (reviewed in [2]).

Several studies have assessed the molecular mechanisms involved in I3C anti-tumor activities (reviewed in [2]). It has been shown that $\mathrm{I} 3 \mathrm{C}$ and derivatives are potent estrogen and androgen receptors antagonists and aryl hydrocarbon receptor agonists. Also, I3C could revert multiple drug resistance in K562 erythroleukemic cells by downregulating Pglycoprotein. I3C and oligomers are potent AKT inhibitors and disrupt AKT-dependent survival pathways. Interestingly, Takada and coworkers [5] showed that I3C suppressed

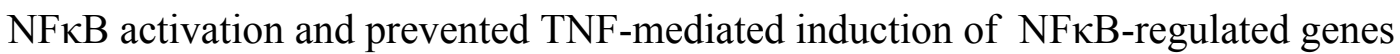
encoding proteins involved in the control of cell proliferation and apoptosis, including cyclin D1, IAP family and BCL2 family proteins, among others.

Previous reports have proposed that the biological activity of $\mathrm{I} 3 \mathrm{C}$ is associated with its capacity of forming oligomers in acidic media, such as the stomach milieu $[2,6]$. Studies in human patients revealed that $\mathrm{I} 3 \mathrm{C}$ and derivatives can be efficiently administered orally $[7,8]$. Importantly, concentrations at $\mu \mathrm{M}$ range of $\mathrm{I} 3 \mathrm{C}$-conjugation products could be reached in plasma and accumulate in tissues after oral intake of these compounds without any 
significant side-effect on the health of the patients [7] and mice [9,10]. Most importantly, clinical trials assessing the effect of oral administration of I3C and its dimer 3,3'diindolylmethane (DIM) have demonstrated their safety in humans [11]. Most interestingly, there is clinical evidence of the effectiveness of $\mathrm{I} 3 \mathrm{C}$ in promoting regression of papillomavirus-dependent precancerous lesions of cervix [12] and larynx [13-15].

Burkitt's lymphoma is a highly aggressive form of non-Hodgkin's B-cell lymphoma that is usually found in extranodal sites or presenting as an acute leukemia [16-18]. Burkitt's lymphomas are often classified in three main clinical variants: 1) the endemic variant, which constitutes the most common childhood malignancy in equatorial Africa and that is associated with Epstein-Barr virus (EBV) infection, a member of the herpesvirus family, 2) the sporadic variant, found in other regions of the world and also frequently affecting children, and 3) the immunodeficiency-associated variant, common in AIDS patients. Available treatment for Burkitt's lymphoma result in about $80 \%$ remission in patients with localized disease, although this success is reduced to $50 \%$ in children with more widespread disease. Furthermore, current treatment involves intensive combination chemotherapy, the need for intrathecal treatment, and risk of tumor lysis syndrome, which precludes its use in the elderly and limits access to treatment to patients in developing countries [19]. For those reasons, it is a necessity to develop new therapies that facilitate access to treatment and minimize therapy-associated toxicity.

In the present study, we have studied whether I3C and other 3-substituted indoles have antitumor activity on Burkitt's lymphoma. Our results show that only I3C and its derivatives are effective in reducing the viability of both latency I and II EBV-positive Burkitt's lymphomas both in vitro and in vivo, while having no effect on EBV-negative BL cell lines. Our data indicate that I3C cytotoxic activity involves cMYC and IAP family 
downmodulation, with subsequent induction of apoptosis. Altogether our results suggest that these compounds might provide a new therapeutic approach for treating patients with endemic (EBV-positive) Burkitt's lymphoma. 


\section{MATERIALS AND METHODS}

2.1. Reagents and antibodies. Indole compounds were purchased from Sigma-Aldrich (St. Louis, MO). Mass spectrometry analysis of indole-3-carbinol (I3C; $1 H$-indole-3-methanol) and 3,3'-diindolylmethane (DIM) confirmed the purity ( $>95 \%$ and $>98 \%$, respectively) and integrity of these compounds as reported by the supplier. The rest of reagents and antibodies are described in supplementary Materials and methods.

2.2. Cell lines and cell culture. Burkitt's lymphoma B cell lines BL-2, BL-41, BL-60.2, Daudi, DG-75, Mutu-1, Raji, Jijoye, Namalwa, Rael, Akata and Ramos and the immortalized EBV-infected lymphoblastoid cell lines JY, Dana, Alewife and IB-4 were cultured in RPMI 1640 medium supplemented with 10\% inactivated fetal calf serum (FCS; Life Technologies, Madrid, Spain), $2 \mathrm{mM}$ L-glutamine, $100 \mathrm{U} / \mathrm{ml}$ penicillin and $100 \mu \mathrm{g} / \mathrm{ml}$ streptomycin at $37^{\circ} \mathrm{C}$ in a humidified atmosphere containing $5 \% \mathrm{CO}_{2}$. Microsatellite analyses of cell lines are provided in supplementary table T1.

2.3. LMP1 expression analysis. Intracellular LMP1 expression was determined using a commercial fixation/permeabilization kit (Fitx\&Perm; Invitrogen Life Technologies), following the manufacturer's instructions. A detailed protocol is provided in supplementary Materials and methods.

2.4. Viability assays. Cells $\left(10^{6}\right.$ cells/ml; $100 \mu \mathrm{l} /$ well $)$ were incubated in 96 -well microtiter plates and cultured in the presence of the indicated reagents. Viability was determined at 24 and $48 \mathrm{~h}$ by using the kit CellTiter $96^{\circ}$ AQueous Assay (Promega Biotech Iberica, Madrid, Spain), following the manufacturer's instructions. The spectrophotometric absorbance of each sample was measured at $490 \mathrm{~nm}$ using the BioTek Synergy Mx microplate reader (BioTek Instruments, Winooski, VT). 
2.5. Apoptosis detection. Apoptosis was determined by annexin V/PI staining. Briefly, cells $\left(2-5 \times 10^{5}\right.$ cells $)$ were harvested and incubated with FITC-labeled annexin V and 1 $\mu \mathrm{g} / \mathrm{ml} \mathrm{PI}$ in binding buffer (5 mM CaCl, $10 \mathrm{mM}$ Hepes, and $140 \mathrm{mM} \mathrm{NaCl})$. After $15 \mathrm{~min}$ in the dark, they were analyzed by flow cytometry.

2.6. Western blot analysis. Western blot was carried out as previously described [20]. A detailed description is provided in supplementary Materials and methods. Densitometry was performed on scanned images using Quantity One ${ }^{\circledR}$ software (Bio-Rad Laboratories), and values were normalized for corresponding controls of each experiment.

\subsection{Determination of mitochondrial depolarization. Mitochondrial transmembrane} potential $\left(\Delta \Psi_{\mathrm{m}}\right)$ was assessed by staining with TMRM. Cells $\left(10^{6}\right.$ cells $\left./ \mathrm{ml}\right)$ were preincubated with $250 \mathrm{nM}$ TMRM for 20 min and then incubated in the presence of the different reagents. At indicated times cells were washed with PBS and analyzed by flow cytometry using a FC 500 MPL cytofluorimeter and the CXP software version 2.1 (Beckman Coulter Inc., Fullerton, CA). An excitation wavelength of $488 \mathrm{~nm}$ and observation wavelength of $585 \mathrm{~nm}$ for red fluorescence were used for analyzing mitochondrial depolarization, which is indicated by the number of cells losing red fluorescence. The protonophore CCCP $(25 \mu \mathrm{M})$ was used as a positive control.

2.8. Quantitative polymerase chain reaction (Q-PCR). Total RNA was extracted from $5 \mathrm{x}$ $10^{6}$ BL-60.2 $(\mathrm{n}=3)$ or Ramos $(\mathrm{n}=1)$ cells using TRIzoL reagent and the PureLink ${ }^{\mathrm{TM}}$ RNA mini kit (Ambion, Life Technologies). Q-PCR was carried out by the Service of Genomics from IIB by means of the Applied Biosystems 7900HT Fast Real-Time PCR System (Applied Biosystems, Life Technologies), using a SYBR Green probe. The primers were as follows: BIRC3 F: 5'TGAGCATGCAGACACATGC and R: 
5'TGGATCATCTCCAGATTCCC; MCL1 F: 5'GGTAATAACACCAGTACGGACG and R: 5'GATAATCTCCAGCGACTGCC; MYC F: 5'AGAGAAGCTGGCCTCCTACC and R: 5'TCGAGGAGAGCAGAGAATC; XIAP F: 5'GCCAGACTATGCTCACCTAACC and R: 5'GCAATTAGGAAAGTGTCGCC. The relative expression of each mRNA was calculated as the $\Delta \mathrm{Ct}$ (value obtained by subtracting the $\mathrm{Ct}$ number of target sample from that of control sample, $18 S$ subunit). The amount of target mRNA relative to $18 S$ mRNA was thus expressed as $2^{-(\Delta \mathrm{Ct})}$. Values are given as the ratio of the target mRNA to $18 \mathrm{~S}$ mRNA.

2.9. In vivo animal studies. $8-12$ weeks-old NOD/SCID (Non-obese Diabetic/Severe Combined Immunodeficiency) male mice were i.p. injected with $10^{7} \mathrm{EBV}$-positive BL Daudi cells. Two weeks after tumor inoculation, mice were administered three times a week by oral gavage either with $150 \mu 1$ ethanol:corn oil (1:9) or $180 \mathrm{mg} / \mathrm{Kg}$ I3C or DIM dissolved in vehicle (ethanol:corn oil (1:9)). Mice showing symptoms of distress and pain (heavy breath, cachexia, lack of reactivity to stimulus) were euthanized. The animal protocols were approved by the Institutional Animal Care and Use Committees from the hosting Institution.

2.10. Data analysis. All experiments were performed at least three times, unless otherwise indicated, obtaining similar results. Treated samples and controls were compared using the paired Student's $t$-test when normally distributed or the paired Wilcoxon's test when not. Survival analysis and correlations were performed using the Kaplan-Meier and the Spearman's or Pearson's tests, respectively. Differences were regarded as significant when $p$ $<0.05$. 


\section{RESULTS}

\subsection{I3C efficiently reduces the viability of EBV-positive Burkitt's lymphoma cell lines in culture but lacks toxicity against EBV-negative Burkitt's lymphoma cell lines and EBV-infected lymphoblastoid cell lines}

$\mathrm{I} 3 \mathrm{C}$ has been reported to induce death of a variety of solid tumors and myeloma cells $[2,5]$ and it has been proven effective in preventing papillomavirus-dependent carcinogenesis in clinical trials [12-15]. Epstein-Barr virus is a member of the Herpesviridae family that is involved in the etiology of Burkitt's lymphoma and other lymphoid malignancies. To determine whether I3C might also be deleterious to EBV-driven tumors, we tested the ability of I3C to induce cell death in Burkitt's lymphoma (BL)-derived cell lines. Thus, we analyzed the effect of increasing I3C concentrations on the viability of a collection of EBVpositive and EBV-negative BL cell lines. As shown in Fig. 1A and supplementary Table T2, I3C efficiently reduced cell viability of EBV-positive BL cell lines in a dose-dependent manner, while I3C did not significantly affect the viability of EBV-negative BL cell lines (Fig. 1B and supplementary Table T2). Indeed these differences in survival between EBVpositive and EBV-negative BL were significant with I3C concentrations as low as $50 \mu \mathrm{M}$ (24 h, $p=0.047 ; 48 \mathrm{~h}, p=0.022$ ), although the higher statistical significance was reached with I3C $200 \mu \mathrm{M}$ at $48 \mathrm{~h}(p<0.0001)$. Furthermore, the effect of I3C on the viability of EBV-positive BL cell lines seemed to be independent of their latency stage. Thus, latency I cell lines, such as Akata, Mutu-1, Rael, BL-60.2, Daudi and Namalwa, that are characterized by the expression of viral protein EBNA1 but not of LMP1, and latency II BL cell lines, such as Jijoye and Raji, which expressed both EBNA1 and LMP1, but lacked EBNA2 expression (Fig. 1D and E, and data not shown), showed comparable reduction in viability in response to increasing $\mathrm{I} 3 \mathrm{C}$ concentrations. 
This result prompted us to determine whether other EBV-carrying cell lines were also sensitive to I3C. For that purpose we tested the effect of I3C on the viability of a variety of immortalized EBV-infected lymphoblastoid cell lines that constitutively express high levels of latency III EBV genes, including EBNA1, EBNA2 (Fig. 1D) and LMP1 (Fig. 1E) and data not shown), which are involved in apoptosis protection [21]. These cells would recapitulate the virus expression patterns seen in infectious mononucleosis and posttransplant lymphoproliferative disorders [22]. As shown in Fig. 1C and supplementary Table T2, I3C had no effect on the viability of any of the EBV-infected lymphoblastoid cell lines tested, thus suggesting that $\mathrm{I} 3 \mathrm{C}$ might only be effective in transformed cells expressing a restricted EBV expression program such as those characteristic of latency I and II.

We next studied whether other 3-substituted indoles also have a deleterious effect on the viability of the EBV-positive BL cell lines BL-60.2 (latency I) and Raji (latency II) (Figure 2). In addition, we also tested the effect on cell viability of indoline, and $1 H$-indole-2methanol. Among the indole compounds tested, only I3C and its C6-methylated analog [(6methyl-1H-indol-3-yl) methanol] caused a significant reduction in the viability of both BL60.2 (Fig. 2A, top panel) and Raji (Fig. 2A, bottom panel). Interestingly, C6-methylated-I3C was more potent than $\mathrm{I} 3 \mathrm{C}$ in both cell lines, indicating that substitution at the benzene-fused ring might enhance the anti-tumor activity of either $\mathrm{I} 3 \mathrm{C}$ or its oligomer products.

\subsection{I3C induces caspase activation and mitochondria membrane depolarization}

To determine the mechanism of I3C-induced cell death we tested whether I3C induces apoptosis or necrosis by assessing annexin V-FITC/PI double staining using flow cytometry analysis. As shown in Fig. 3A, I3C $(200 \mu \mathrm{M})$ efficiently triggered apoptosis, as evidenced by the labeling of dying cells with annexin V (15\%) and annexin V/PI (52\%) after $15 \mathrm{~h}$ of 
incubation. Consistent with the induction of apoptosis, the pan-caspase inhibitor Z-VADfmk efficiently blocked I3C-dependent cell death.

The analysis of the apoptosis pathways triggered by I3C in EBV-positive BL cell lines BL60.2 and Raji showed the proteolytic activation of apical caspases of both the extrinsic (caspase 8) and intrinsic (caspase 9) apoptosis pathways, as well as of executioner caspase 3 (Fig. 3B). PARP cleavage was also readily observed after I3C-treatment, and I3C-dependent PARP cleavage and caspases activation were prevented by incubation of cells with the caspase inhibitor Z-VAD-fmk in all EBV-positive BL cell lines tested, including Raji, BL60.2 (Fig. 3B) and Daudi (supplementary Fig. S1). In contrast, I3C failed to trigger caspase activation and PARP cleavage in EBV-negative BL cell line Ramos and in EBV-infected lymphoblastoid cell line Dana, in agreement with the lack of effect of I3C on the viability of these cell lines (Fig. 3B).

Interestingly, we also observed phosphorylation in Ser139 of histone H2A.X in response to I3C treatment. Induction of phosphorylated H2A.X (also known as $\gamma-\mathrm{H} 2 \mathrm{~A} . \mathrm{X}$ ) is an early event occurring after DNA damage and is dependent on ATM/ATR [23,24]. However, a caspase-dependent induction of $\gamma$-H2A.X has also been described, which is dependent on the proteolytic activation of MTS-1 kinase by caspases $[25,26]$. Our results show that incubation of EBV-positive BL cell lines BL-60.2, Raji, and Daudi with I3C caused a dose-dependent induction of $\gamma$-H2A.X, which is observed at I3C concentrations as low as 20-50 $\mu \mathrm{M}$ (Fig. 3B and supplementary Fig. S1). Moreover, incubation of cells with Z-VAD-fmk completely abrogated $\gamma-\mathrm{H} 2 \mathrm{~A} . \mathrm{X}$ induction, thus indicating that this event was fully dependent on caspase activation. In contrast, I3C failed to induce $\gamma$-H2A.X induction in EBV-negative BL cell line Ramos and EBV-infected lymphoblastoid cell line Dana (Fig. 3B), in agreement with our results, indicating that $\mathrm{I} 3 \mathrm{C}$ does not trigger caspase activation in these cell lines. 
To further characterize the pro-apoptotic effect of I3C, we next assessed whether this compound altered mitochondrial membrane potential $(\Delta \psi \mathrm{m})$, which is a critical event preceding cytochrome $c$ release and the formation of the apoptosome. Indeed, $\Delta \psi_{\mathrm{m}}$ depolarization was observed in BL-60.2 cells as early as $5 \mathrm{~h}$ after incubation with I3C. In Raji cells, $\Delta \psi_{\mathrm{m}}$ depolarization took longer but was evident after $8 \mathrm{~h}$ of incubation with I3C (Fig. 3C). Consistent with I3C-mediated mitochondrial depolarization, we found very limited production of both mitochondrial ROS production (supplementary Materials and methods and supplementary Fig. S2A). Also, cytosolic ROS did not accumulate in response to $\mathrm{I} 3 \mathrm{C}$ in these cell lines and time frame (supplementary Materials and methods and supplementary Fig. S2B), thus suggesting that ROS production is not required for I3Cmediated apoptosis induction in EBV-positive BL cells.

On other hand, there are several reports supporting a role for I3C in cell cycle arrest $[2,27]$. However, our results using BL-60.2 cells did not show any I3C-dependent alteration of cell cycle, and the percentage of cells in $\mathrm{G}_{1}, \mathrm{~S}$ and $\mathrm{G}_{2} / \mathrm{M}$ were similar, irrespective of the presence or absence of I3C in the culture (supplementary Materials and methods and supplementary Fig. S3). Moreover, our results also indicate that I3C-induced apoptosis in BL-60.2 cells is cell cycle-independent since induction of apoptosis did not correlate with any significant alteration of the percentage of cells going through the different phases of the cell cycle (supplementary Fig. S3).

\subsection{I3C alters the levels of expression of proteins involved in the control of cell survival in EBV-positive BL cell lines}

We next examined the effect of $\mathrm{I} 3 \mathrm{C}$ on the expression levels of several proteins known to regulate cell survival and apoptosis, including the BCL2 family members BCL2, MCL1, BCLX $_{\mathrm{L}}$ and BAX, the inhibitors of apoptosis (IAP)-family members cIAP1/2 and XIAP, 
and the protease-deficient caspase 8 homolog cFLIPL. For these experiments, EBV-positive BL cell lines BL60.2 (Fig. 4A), Raji (Fig. 4B) and Daudi (supplementary Fig. S1), the EBVnegative BL cell line Ramos (Fig. 4C) and the EBV-infected lymphoblastoid cell lines Dana (Fig. 4D) were incubated in the presence of increasing concentrations of I3C (0-200 $\mu \mathrm{M})$ for 24 h. As shown in Fig. 4 and supplementary Fig. S1, I3C causes striking downregulation of both XIAP and cIAP1/2 in EBV-positive BL cell lines BL-60.2, Daudi, and Raji, while no effect on these proteins was observed in EBV-negative BL Ramos cells or in EBV-infected lymphoblastoid cell line Dana. This downmodulation was caspase-independent, since it was not prevented by the caspase inhibitor Z-VAD-fmk.

In addition, I3C also caused evident downmodulation of MCL1 in all EBV-positive BL cell lines, while slight downmodulation of BCLX $\mathrm{L}_{\mathrm{L}}$ was only observed in Raji cells. No significant effect of I3C on the expression levels of BCL2, BAX and $\beta$-ACTIN (used as loading control) was observed. In contrast, I3C caused cFLIPL expression upregulation in both Raji and BL-60.2 cells.

\subsection{Differential effects of I3C on the expression of transcription factors and modulators related to Burkitt's lymphoma etiology}

The defining and most relevant genetic alteration involved in Burkitt's lymphoma etiology is the (8:14) translocation that causes cMYC overexpression. The mechanism by which cMYC upregulation contributes to BL cell transformation is related to its effects on cell proliferation, genomic instability and deregulated apoptosis (reviewed in [16]). To assess whether I3C has any effect on cMYC expression, BL-60.2 (Fig. 5A), Raji (Fig. 5B), Ramos (Fig. 5C) and Dana (Fig. 5D), as well as Daudi (supplementary Fig. S1) cell lines were incubated in the presence of I3C $(0-200 \mu \mathrm{M})$ for $24 \mathrm{~h}$. As expected, cMYC was overexpressed in BL cell lines, but it was undetectable in EBV-infected lymphoblastoid cell 
line Dana. Our results showed that $\mathrm{cMYC}$ was downregulated by $\mathrm{I} 3 \mathrm{C}$ at concentrations as low as 20-50 $\mu \mathrm{M}$ in all EBV-positive BL cell lines tested, including BL-60.2, Daudi and Raji cells (Fig. 5 and 6, and supplementary Fig. S1). This downmodulation takes place very rapidly, being observed before the induction of apoptosis, as shown in Fig. 6A. Consistent with this result, cMYC downmodulation was not prevented by Z-VAD-fmk (Fig. 5 and supplementary Fig. S1).

It is worth mentioning that upregulation of CFLIP $_{\mathrm{L}}$ expression observed in Raji and BL-60.2 cells (Fig. 4) is consistent with cMYC inhibition, since this transcription factor is a known transcriptional repressor of CFLAR, the gene encoding cFLIPL [28]. In contrast, I3C did not have any effect on cMYC expression in EBV-negative BL Ramos cells, even though this cell line also harbors the 8:14 MYC translocation found in Raji and BL-60.2 cells.

Besides cMYC, other transcription factors such as E2F1 [29], E2F4 [30], TCL1 [31] and transcription modulators such as the retinoblastoma-related protein $\mathrm{pRb} 2 / \mathrm{p} 130$ [32] have been involved in BL etiology. Thus, we also studied the effect of I3C on these transcription factors. Expression levels of E2F4 and pRb2/p130 were also reduced by I3C in Raji and BL60.2 cells, although their expression levels remained unaltered in Ramos and Dana cells. However, E2F4 and pRb2/p130 downmodulation in EBV-positive BL cells was caspasedependent as it was partially reverted by Z-VAD-fmk. In contrast, the expression levels of mutated p53, E2F1 and TCL1, were not significantly affected by I3C in any of the cell lines tested.

We also assessed the effect of $\mathrm{I3C}$ on EBNA1 protein levels. EBNA1 is the only viral protein that is expressed in all EBV-positive BL cell lines and primary tumors and has been involved in apoptosis protection [33] and transcription reprogramming of infected cells [34]. As shown in Fig. 5A, B, and supplementary Fig. S1, I3C causes the reduction of EBNA1 
expression levels in EBV-positive BL cell lines, particularly in BL-60.2 cells, although this reduction was prevented by Z-VAD-fmk, thus implying that it was dependent on the activation of caspases. In contrast, EBNA1 expression levels in EBV-infected lymphoblastoid cell line Dana remained unaltered by I3C.

\subsection{I3C downmodulates $M Y C, B I R C 3$ and XIAP transcription}

To further assess the mechanism involved in protein downmodulation in response to $\mathrm{I} 3 \mathrm{C}$, we checked whether it was caused by transcriptional inhibition. We therefore determined the expression levels of the mRNAs encoding cIAP2 (BIRC3), XIAP $(X I A P), \mathrm{cMYC}(M Y C)$ and MCL1 (MCL1) by Q-PCR. EBV-positive Burkitt's lymphoma BL-60.2 cells and EBVnegative BL Ramos cells were incubated with $100 \mu \mathrm{M} \mathrm{I3C}$ for $15 \mathrm{~h}$, then total RNA was extracted, retrotranscribed and subjected to real time PCR using primers specific for the genes of interest. As shown in Fig. 7, we observed a significant reduction in the levels of mRNA encoding cIAP2, XIAP and cMYC in BL-60.2 cells treated with $\mathrm{I} 3 \mathrm{C}$, while the expression levels of these mRNAs were not affected by I3C in Ramos cells. These results strongly suggest that transcriptional inhibition is involved in the downmodulation of the expression of these proteins in response to I3C in EBV-positive BL cells. In contrast, $M C L 1$ mRNA levels were not significantly affected by I3C in BL-60.2 and Ramos cells.

It is worth mentioning that previous report by Takada and coworkers [5] in myeloma cells showed that I3C inhibited NFKB causing downmodulation of different targets involved in the control of apoptosis, including cIAP1/2, XIAP, and cFLIPL. However, NFkB1 activity has been shown to be suppressed in Burkitt's lymphoma [35]. Our data have shown that incubation of Raji cells with $200 \mu \mathrm{M} \mathrm{I3C}$ at $2 \mathrm{~h}$ (not shown), 9h and $24 \mathrm{~h}$ (supplementary Fig. S4A) did not alter the subcellular localization of RELA (p65) and NFkB1 (p50), which 
are mostly found in cytosol, and that it did not have any effect on p100 processing into p52 (NFkB2) nor did alter its subcellular localization. However, we observed downmodulation of cMYC, XIAP and cIAP1/2 expression after 9h of incubation with I3C (supplementary Fig. S4A), suggesting that NFאB inhibition is not likely involved in I3C-mediated downmodulation of these proteins in EBV-positive BL cells. Moreover, as shown in supplementary Fig. S4B, immunohistochemical analysis of RELA (p65) expression in EBVpositive BL Daudi cells xenografted in NOD/SCID mice showed that treatment either with vehicle or I3C did not altered RELA (p65) expression levels nor did it affect its subcellular localization which was prominently cytosolic in both conditions. These results further confirm that I3C do not alter RELA (p65) expression and subcellular localization even in long in vivo I3C treatments (see below). Furthermore, downmodulation of cMYC, XIAP and cIAP $1 / 2$ occurred in the absence of caspase activation, as determined by the absence of PARP cleavage. In contrast, EBNA1 expression was not affected by I3C after 9h but its expression was dramatically reduced after $24 \mathrm{~h}$, coincident with overt apoptosis (supplementary Fig. S4A).

\subsection{I3C and its dimer 3,3'-diindolylmethane (DIM) reduce tumor burden and prolong survival of xenotransplanted mice}

Next, we investigated whether I3C and its dimer DIM could reduce tumor burden and prolong survival of NOD/SCID mice that were i.p. xenotransplanted with EBV-positive BL Daudi cells. DIM (Fig. 8A) is an I3C dimer, which is the major product formed by I3C condensation in acidic aqueous solutions, similar to the conditions found in the stomach [6]. DIM has been proposed to be the physiologically active form of I3C (reviewed in [1]). Mice were i.p. inoculated with Daudi cells and were left untreated for 2 weeks to allow tumor 
implantation. Then, mice were administered 3 times a week by oral gavage with $150 \mu \mathrm{l}$ vehicle (ethanol:corn oil 1:9) with or without either I3C or DIM $(180 \mathrm{mg} / \mathrm{Kg})$.

At the time of death, mice treated with vehicle showed disseminated lymphoma $(2.18 \pm 0.26$ g; $\mathrm{n}=9$ ) (Fig. 8B). However, although I3C-treated mice also had disseminated lymphoma at the time of death, the weight of the tumor $(1.3 \pm 0.3 \mathrm{~g} ; \mathrm{n}=7)$ was significantly reduced compared to that of vehicle-treated mice $(p=0.02)$ (Fig. 8B). In addition, as shown in Figure $8 \mathrm{C}$, survival time of I3C-treated mice was longer than that of vehicle-treated mice, although it did not reach statistical significance $(p=0.2)$. As shown in Fig. 8D, mice treated with DIM $(n=6)$ survived significantly longer than mice treated with vehicle only $(p=$ 0.012), and 3 mice in the experiment were alive at day 121 while all mice in the control group were dead between days 62-70 (Fig. 8D). Moreover, the weight of the tumor in DIMtreated mice at the time of death or sacrifice was $0.6 \pm 0.2 \mathrm{~g}$ (vehicle $v s \mathrm{DIM}, p=0.0005$ ) (Fig. 8B).

To further assess the effect of I3C and DIM in vivo, we performed a histochemical analysis of tumors isolated from mice treated with vehicle, I3C and DIM. As shown in supplementary Fig S5, cMYC expression was prominent in the Daudi tumors isolated from vehicle-treated mice. However, cMYC expression was strikingly downmodulated in mice treated with $\mathrm{I} 3 \mathrm{C}$, which also evidenced the presence of scattered pyknotic nuclei indicative of apoptosis. Most interestingly, tumors from DIM treated mice showed an even larger reduction in cMYC expression and abundance of pyknotic nuclei. Altogether, these results indicate that, compared to I3C, DIM has a more potent anti-tumor effect in vivo against EBV-positive BL Daudi cells. 


\section{DISCUSSION}

In this report we have shown that I3C, a naturally occurring dietary component found in broadly consumed vegetables of the Brassica genus, shows potent anti-tumor activity against EBV-positive BL cell lines. I3C is derived from glucosinolates produced by plants such as broccoli, Brussels sprouts, and cabbage, where it is found at concentrations ranging from $0.2-4 \mathrm{mg} / \mathrm{g}$ [36]. Previous reports have proposed that the biological activity of I3C is associated with its capacity of forming oligomers in acidic media, such as the stomach milieu [6]. Its major condensation product is its dimer DIM, which can reach $\mu \mathrm{M}$ concentrations in plasma and organs similar to those used in this study. Indeed, the area under the curve value for I3C-condensation products after I3C intake (1g) in human plasma was $22 \mu \mathrm{M} \mathrm{x} \mathrm{h} \mathrm{[7],} \mathrm{and} 160 \mu \mathrm{M} \mathrm{x} \mathrm{h}$ in plasma and 1.4 mmoles $\mathrm{x} \mathrm{h} \mathrm{g} \mathrm{g}^{-1}$ in liver of mice after oral intake of $7.5 \mathrm{mg}$ of DIM, the major condensation product of I3C $[9,10]$.

The specificity of the anti-tumor effect of I3C against EBV-positive BL cell lines is highlighted by the fact that several other 3 -substituted indoles and $1 H$-indole-2-methanol had no significant effect on the viability of EBV-positive BL cell lines. Interestingly, most of the inactive 3 -substituted indoles tested present moieties that are either bioisosteres of the 3-hydroxymethylene possessed by I3C or slightly modified. Consequently, these compounds should generate similar chemical interactions with the $\mathrm{I} 3 \mathrm{C}$ biological targets and should also have some anti-tumor activity, but they do not, thus further suggesting that $\mathrm{I} 3 \mathrm{C}$ is a pro-drug that can be biotransformed into active oligomers. Our results showing the lack of anti-tumor activity of the 3-substituted indoles tested and of $1 H$-indole-2-methanol would be in support of this hypothesis since none of these compounds can form oligomers in physiologic conditions or in acidic media. In this regard, the I3C dimer DIM has been shown to be the major $\mathrm{I} 3 \mathrm{C}$ condensation product formed in neutral and acidic aqueous medium and it has 
been proposed to be the biologically active form of $\mathrm{I} 3 \mathrm{C}$ both in vivo and in vitro, since conversion of I3C to DIM in cell cultures has also been described [37,38]. However, it is worth noting that the low water solubility of DIM $\left(1.4 \mu \mathrm{M}\right.$, EPISuite ${ }^{\mathrm{TM}}$, U.S. Environmental Protection Agency) has limited any comparative study of the in vitro anti-tumor activity of I3C and DIM on EBV-positive BL cell lines. However, our in vivo studies did indeed demonstrate that DIM has a more potent anti-tumor effect in vivo compared to I3C. In this regard, NOD/SCID mice xenografted with EBV-positive BL Daudi cells treated with either vehicle, I3C or DIM showed that although I3C caused reduction of tumor growth and slightly increased survival time compared to vehicle treated mice, DIM treatment caused a significantly larger reduction of tumor weight and prolonged survival of the xenografted mice.

Previous results have shown the effectiveness of $\mathrm{I} 3 \mathrm{C}$ in clinical trials in patients with precancerous lesions of the cervix and laryngeal papillomas, both of which are related to infection with human papillomavirus. Our results showing that $\mathrm{I} 3 \mathrm{C}$ efficiently induces apoptosis of all tested BL cell lines infected with EBV, a member of the herpesvirus family, but failed to reduce the viability of any EBV-negative BL analyzed, would suggest that I3C might be active against tumors in which virus infection contributes to tumor transformation. In this regard, EBV asymptomatically infects over $90 \%$ of the world adult population and its involvement in the etiology of endemic BL is well established. Although the contribution of EBV to tumor transformation is yet to be elucidated, protection from apoptosis seems to be implicated [16,39]. Interestingly, the majority of EBV-positive Burkitt's lymphomas and derived cell lines are latency I, which is characterized by the sole expression of EBNA1 and non-coding EBER RNAs. However, some EBV-positive BL cell lines in culture and lymphomas such as EBV-positive Hodgkin lymphoma and EBV-positive NK/T cell 
lymphoma, express latency II genes, including LMP1 [22,40]. Indeed, the EBV-positive cell lines that we have used in this study are mostly latency I, expressing only EBNA1, but in two of them, Jijoye and Raji, expression of LMP1 was also detected, thus implying that EBV-positive BL cell lines were sensitive to I3C irrespective of LMP1 expression.

We have also investigated whether I3C might have an effect on the viability of cells from other EBV-dependent pathologies in which a majority of the virus genome is expressed (latency III). For these experiments we used EBV-infected lymphoblastoid cell lines. Our results showed that $\mathrm{I} 3 \mathrm{C}$ had no effect on the viability of these cells, thus arguing against any therapeutic effect of I3C on diseases in which latency III viral proteins are expressed, such as post-transplant lymphoproliferative disorders and infection mononucleosis. These results also suggest that either the higher levels of EBNA1 that are expressed in latency III cells or, most likely, latency III-specific proteins may protect from I3C-induced cytotoxicity.

The defining oncogene in Burkitt's lymphoma is $M Y C$. Translocations that juxtapose MYC on chromosome 8 with the $\operatorname{IgH}$ genes on chromosome 14 or, less frequently, with $\operatorname{IgL}$ genes, are found in the vast majority of BL cases, whether they are or not associated with EBV. Overexpression of cMYC activates both proliferation and apoptosis. In the case of EBVpositive $\mathrm{BL}$, it has been proposed that $\mathrm{EBV}$ promotes $\mathrm{cMYC}$ transformation by counteracting the pro-apoptotic activities of cMYC $[21,33,41]$. In addition, it is well established that $\mathrm{cMYC}$ overexpression represses part of the virus transcription program restricting it to latency I, thus implying a tight relation between cMYC upregulation and EBV infection in the development of BL $[42,43]$. Our studies about the effect of I3C on the expression of different proteins relevant to BL etiology and on the regulation of cell death showed that cMYC was one of the most sensitive targets to I3C treatment. Indeed, downmodulation of cMYC expression was readily observed with $\mathrm{I} 3 \mathrm{C}$ concentrations as low 
as 20-50 $\mu \mathrm{M}$ and just $2.5 \mathrm{~h}$ after I3C addition in EBV-positive BL BL-60.2, Raji, and Daudi. However, no effect on cMYC expression was observed in EBV-negative BL Ramos cell line. This is surprising since BL-60.2, Raji, Daudi and Ramos cells harbor the $\mathrm{t}(8: 14)$ MYC translocation, although the $I g H / c M Y C$ junctions of these translocations are different and might have different regulatory requirements [44]. Interestingly, the observation that expression of $\mathrm{cFLIP}_{\mathrm{L}}$, the product of $C F L A R$, a gene transcriptionally repressed by $\mathrm{cMYC}$ [28], is upregulated by I3C in EBV-positive BL cells is in support of a functional implication of cMYC downmodulation in the proapoptotic activity of I3C. Interestingly, $\mathrm{cFLIP}_{\mathrm{L}}$ has been shown to play a dual role in apoptosis by either preventing or promoting caspase 8 activation and function $[45,46,47,48]$. In fact, many evidences indicate that cFLIP $_{\mathrm{L}}$ can associate with and promote caspase 8 activation, thus acting as a bonafide proapoptotic molecule depending on its expression levels and cell context $[45,49,50]$. I3C-mediated downmodulation of cIAP $1 / 2$ and XIAP in response to I3C treatment would have a direct impact on the ability of EBV-positive BL cells to survive. Our data indicate that cIAP1/2 and XIAP expression is strikingly downmodulated by I3C in a process that is transcriptionally regulated and caspase-independent. As shown in Fig. 6, downmodulation of cMYC and IAP proteins clearly precede caspase activation, as determined by caspasedependent H2A.X phosphorylation, which is a highly sensitive marker of caspase activity, suggesting that suppressing these proteins is a key requirement for I3C-mediated cytotoxicity in EBV-positive BL cells.

Finally, it is intriguing why the cytotoxic effect of I3C and derivatives and the effect of this compound on cMYC and IAP proteins expression are only observed in BL cells with latency I/II EBV program and not in EBV-negative BL cells. One explanation would be that I3C is interfering with the cellular survival program established by the virus. However, it is 
possible that EBV-negative BL rely on additional survival factors or enzymes that render I3C inactive. Further research on this matter is warranted.

In conclusion, we show that $\mathrm{I} 3 \mathrm{C}$ and derivatives efficiently promote both in vitro and in vivo apoptosis of latency I and II EBV-positive BL cell lines, while having no effect on EBVnegative BL or in EBV-infected LCLs (latency III). The specific pro-apoptotic effect of I3C in EBV-positive BL cells correlates with the downmodulation of cMYC expression and of IAP family members cIAP1/2 and XIAP at both protein and mRNA levels. The low toxicity of I3C and its dimer DIM, already confirmed in clinical trials, supports their use in clinics to treat patients with endemic (EBV-positive) Burkitt's lymphoma. 


\section{COMPETING INTEREST}

The authors declare no financial conflict of interest.

\section{ACKNOWLEDGMENTS}

This work was supported by grants from the Instituto de Salud Carlos III (PI08/0170 and PI12/01135), and the Ministerio de Economia y Competitividad (SAF2011-23846) to JMZ. GP-C was the recipient of a Junta de Ampliacion de Estudios (JAE)-Doc contract from CSIC. We are grateful to Dr. John C. Reed (Sanford-Burnham Medical Research Institute, La Jolla, CA), Dr. Miguel R. Campanero (Instituto de Investigaciones Biomedicas “Alberto Sols”, Madrid), Dr. Paloma Perez-Aciego and Ignacio Losada (Fundacion LAIR, Madrid), and Dr. Francisco Sanchez-Madrid and Dr. Danay Cibrian (Centro Nacional de Investigaciones Cardiovasculares) for kindly providing reagents, cell lines and technical support. We are grateful to Dr. Nerea Rebolleda and Patricia Franzka for helpful discussions, and Maria G. Gonzalez-Bueno, Genesis Martin-Fernandez, the personnel of the Comparative Medicine and Genomics facilities of the Instituto de Investigaciones Biomedicas “Alberto Sols” and of the Centro Nacional de Investigaciones Cardiovasculares for excellent technical support. 


\section{FIGURE LEGENDS}

Figure 1. I3C induces cell death in EBV-positive BL cell lines but not in EBV-negative BL cell lines or EBV-infected lymphoblastoid cell lines (LCL). EBV-positive BL (A), EBVnegative BL (B), and EBV-infected LCL (C) cell lines $\left(10^{6}\right.$ cells $\left./ \mathrm{ml}\right)$ were cultured in triplicates in medium without or with increasing doses of I3C $(20-200 \mu \mathrm{M}) .48 \mathrm{~h}$ later, the percentage of viable cells was determined considering the control value as $100 \%$ viability. (D) A total of $12 \mu \mathrm{g}$ of protein were subjected to $8 \%$ SDS-PAGE and immunoblotting with specific antibodies against the indicated proteins. ERK2 was used as a loading control. LMP1 expression is indicated as positive or negative considering the result obtained by flow cytometry. (E) For LMP1 expression, $10^{6}$ cells of each cell line were fixed and permeabilized, and incubated with anti-LMP1 1:100 and then with goat anti-mouse F(ab')2-FITC 1:100. Cells were analyzed by flow cytometry.

\section{Figure 2. Effect of different 3-substituted indoles on EBV-positive BL cell lines viability}

(A) BL-60.2 and Raji cells were cultured in triplicates in medium containing vehicle control (< $0.02 \%$ ethanol or DMSO) or with increasing doses of the indicated compounds $(20-200 \mu \mathrm{M})$. After $24 \mathrm{~h}$ and $48 \mathrm{~h}$, the percentage of viable cells was determined by a colorimetric assay considering the control condition as $100 \%$ viability. (B) Structural formula of the chemical compounds used in (A).

Figure 3. I3C induces apoptosis in EBV-positive BL cell lines by a caspase-dependent mechanism. (A) BL-60.2 cells $\left(10^{6}\right.$ cells $\left./ \mathrm{ml}\right)$ were cultured in triplicates in medium containing vehicle control $(0.02 \%$ ethanol/DMSO) or with $200 \mu \mathrm{M} \mathrm{I3C}$. When indicated, cells were preincubated with $100 \mu \mathrm{M}$ Z-VAD-fmk (ZVAD) for $30 \mathrm{~min}$. After $15 \mathrm{~h}$, the 
percentage of viable cells was determined by flow cytometry analysis of annexin-V FITC and PI. (B) EBV-positive BL BL-60.2 and Raji cells, EBV-negative BL Ramos cells and EBV-infected LCL Dana $\left(10^{6}\right.$ cells $\left./ \mathrm{ml}\right)$ were cultured in medium with vehicle $(0.02 \%$ ethanol/DMSO) or with increasing concentrations of I3C (20-200 $\mu \mathrm{M})$. When indicated, cells were preincubated with $100 \mu \mathrm{M}$ Z-VAD-fmk (ZVAD) for $30 \mathrm{~min}$. After $24 \mathrm{~h}$ of incubation cells were lysed and a total of $12 \mu \mathrm{g}$ of protein were subjected to $8-13 \%$ SDSPAGE and immunoblotting with specific antibodies against the indicated proteins. p65NFkB was used as a loading control. (C) I3C induces mitochondrial depolarization. BL-60.2 and Raji cells $\left(10^{6}\right.$ cell $\left./ \mathrm{ml}\right)$ were preincubated with $250 \mathrm{nM}$ TMRM for $30 \mathrm{~min}$ and then cultured in the presence of vehicle control $(<0.02 \%$ ethanol $)$ or $200 \mu \mathrm{M}$ I3C. At indicated times, cells were harvested and analyzed by flow cytometry in the FL-2 channel. Cells cultured with $25 \mu \mathrm{M}$ CCCP were used as a positive control of mitochondria membrane depolararization.

Figure 4. Analysis of the effect of I3C on the expression of different proteins implicated in the control of apoptosis. BL-60.2 (A), Raji (B), Ramos (C) or Dana (D) cells $\left(10^{6}\right.$ cells/ml) were cultured in medium containing vehicle control $(0.02 \%$ ethanol/DMSO) or with increasing doses of I3C $(20-200 \mu \mathrm{M})$. When indicated, cells were preincubated with $100 \mu \mathrm{M}$ Z-VAD-fmk (ZVAD) for $30 \mathrm{~min}$. After $24 \mathrm{~h}$ of incubation cells were lysed in Laemmli buffer and sonicated. A total of $12 \mu \mathrm{g}$ of protein from each sample were subjected to $8-10 \%$ SDS-PAGE and immunoblotting with specific antibodies as indicated. $\beta$-ACTIN was used as a loading control.

Figure 5. Analysis of the effect of I3C on the expression of transcription factors and cofactors involved in BL etiology. BL-60.2 (A), Raji (B), Ramos (C) or Dana (D) cells $\left(10^{6}\right.$ cells $/ \mathrm{ml})$ were cultured in medium containing vehicle control $(0.02 \%$ ethanol/DMSO) or with 
increasing doses of I3C (20-200 $\mu \mathrm{M})$. When indicated, cells were preincubated with $100 \mu \mathrm{M} \mathrm{Z}$ VAD-fmk (ZVAD) for $30 \mathrm{~min}$. After $24 \mathrm{~h}$ of incubation cells were lysed and a total of $12 \mu \mathrm{g}$ of protein from each sample were subjected to $8-13 \%$ SDS-PAGE and immunoblotting with specific antibodies as indicated. $\beta$-ACTIN was used as a loading control.

\section{Figure 6. Analysis of I3C-dependent expression downmodulation and activation of cMYC} and pro- and anti-apoptotic proteins. (A) Raji cells $\left(10^{6}\right.$ cells $\left./ \mathrm{ml}\right)$ were cultured with vehicle control $(<0.02 \%$ ethanol $)$ or $200 \mu \mathrm{M}$ I3C for indicated times. Cells were lysed in Laemmli buffer and sonicated. In all cases, $12 \mu \mathrm{g}$ of protein were subjected to 8-13\% SDS-PAGE and immunoblotting with specific antibodies as indicated. $\beta$-ACTIN expression was used as a loading control. It is shown the percentage of expression of the different proteins normalized for $\beta$-ACTIN. (B) Raji, (C) BL-60.2, and (D) Daudi cells $\left(10^{6}\right.$ cells $\left./ \mathrm{ml}\right)$ were cultured with vehicle control $(<0.02 \%$ ethanol) or increasing doses of I3C $(20-200 \mu \mathrm{M})$ for $24 \mathrm{~h}$. Cells were lysed in Laemmli buffer and sonicated. In all cases, $12 \mu \mathrm{g}$ of protein were subjected to $8-13 \%$ SDSPAGE and immunoblotting with specific antibodies as indicated. $\beta$-ACTIN expression was used as a loading control. It is shown the percentage of expression of the different proteins normalized for $\beta$-ACTIN.

\section{Figure 7. I3C-mediated protein downmodulation is caused by transcription inhibition.}

BL-60.2 $(\mathrm{n}=3)$ and Ramos $(\mathrm{n}=1)$ cells $\left(10^{6}\right.$ cells $\left./ \mathrm{ml}\right)$ were cultured with vehicle control $(<$ $0.02 \%$ ethanol) or $100 \mu \mathrm{M} \mathrm{I} 3 \mathrm{C}$ for $15 \mathrm{~h}$. RNA was extracted and gene expression analysis of the indicated genes was carried out by Q-PCR. BL-60.2 data show the mean \pm standard deviation of the relative mRNA expression in cells treated with $\mathrm{I} 3 \mathrm{C}$ respective to their levels in non-treated cells. Statistical significance was obtained using two tails paired Student's $t$-Test. 
Figure 8. Treatment with I3C or DIM reduces tumor burden and prolongs survival of a Burkitt's lymphoma xenograft model. (A) Structural formula of I3C and DIM. (B) Comparison analysis of the tumor weight developed by mice treated with either vehicle, I3C or DIM. NOD/SCID mice were injected i.p. with $10^{7}$ Daudi cells. After two weeks animals were treated orally three days in a week with vehicle alone (control) $(n=9)$, or containing either 180 $\mathrm{mg} / \mathrm{Kg}$ of I3C $(\mathrm{n}=7)$ or $180 \mathrm{mg} / \mathrm{Kg}$ of DIM $(\mathrm{n}=6)$. Mean \pm SEM is shown. Statistical significance was assessed by unpaired $t$ Student analysis. (C) Kaplan-Meier survival curves of vehicle-treated $(\mathrm{n}=8)$ vs I3C-treated mice $(\mathrm{n}=8)$. (D) Kaplan-Meier survival curves of vehicletreated $(\mathrm{n}=5)$ vs DIM-treated mice $(\mathrm{n}=7)$. Differences were significant $(p=0.012)$. 


\section{BIBLIOGRAPHY}

1 Banerjee S, Kong D, Wang Z, Bao B, Hillman GG, Sarkar FH. Attenuation of multi-targeted proliferation-linked signaling by 3,3'-diindolylmethane (dim): From bench to clinic. Mutat Res 2011;728:47-66.

2 Aggarwal BB, Ichikawa $\mathrm{H}$. Molecular targets and anticancer potential of indole-3-carbinol and its derivatives. Cell Cycle 2005;4:1201-1215.

3 Weng JR, Tsai CH, Kulp SK, Chen CS. Indole-3-carbinol as a chemopreventive and anticancer agent. Cancer Lett 2008;262:153-163.

$4 \quad \mathrm{Kim}$ YS, Milner JA. Targets for indole-3-carbinol in cancer prevention. J Nutr Biochem 2005;16:65-73.

5 Takada Y, Andreeff M, Aggarwal BB. Indole-3-carbinol suppresses nf-kappab and ikappabalpha kinase activation, causing inhibition of expression of nf-kappab-regulated antiapoptotic and metastatic gene products and enhancement of apoptosis in myeloid and leukemia cells. Blood 2005;106:641-649.

6 De Kruif CA, Marsman JW, Venekamp JC, Falke HE, Noordhoek J, Blaauboer BJ, Wortelboer $\mathrm{HM}$. Structure elucidation of acid reaction products of indole-3-carbinol: Detection in vivo and enzyme induction in vitro. Chemico-biological interactions 1991;80:303-315.

7 Reed GA, Arneson DW, Putnam WC, Smith HJ, Gray JC, Sullivan DK, Mayo MS, Crowell JA, Hurwitz A. Single-dose and multiple-dose administration of indole-3-carbinol to women: Pharmacokinetics based on 3,3'-diindolylmethane. Cancer Epidemiol Biomarkers Prev 2006;15:2477-2481.

8 Reed GA, Peterson KS, Smith HJ, Gray JC, Sullivan DK, Mayo MS, Crowell JA, Hurwitz A. A phase i study of indole-3-carbinol in women: Tolerability and effects. Cancer Epidemiol Biomarkers Prev 2005;14:1953-1960.

9 Anderton MJ, Manson MM, Verschoyle RD, Gescher A, Lamb JH, Farmer PB, Steward WP, Williams ML. Pharmacokinetics and tissue disposition of indole-3-carbinol and its acid condensation products after oral administration to mice. Clin Cancer Res 2004;10:5233-5241.

10 Anderton MJ, Manson MM, Verschoyle R, Gescher A, Steward WP, Williams ML, Mager DE. Physiological modeling of formulated and crystalline 3,3'-diindolylmethane pharmacokinetics following oral administration in mice. Drug metabolism and disposition: the biological fate of chemicals 2004;32:632-638.

11 Minich DM, Bland JS. A review of the clinical efficacy and safety of cruciferous vegetable phytochemicals. Nutrition reviews 2007;65:259-267.

12 Bell MC, Crowley-Nowick P, Bradlow HL, Sepkovic DW, Schmidt-Grimminger D, Howell P, Mayeaux EJ, Tucker A, Turbat-Herrera EA, Mathis JM. Placebo-controlled trial of indole-3-carbinol in the treatment of cin. Gynecol Oncol 2000;78:123-129.

13 Coll DA, Rosen CA, Auborn K, Potsic WP, Bradlow HL. Treatment of recurrent respiratory papillomatosis with indole-3-carbinol. American journal of otolaryngology 1997;18:283-285.

14 Auborn K, Abramson A, Bradlow HL, Sepkovic D, Mullooly V. Estrogen metabolism and laryngeal papillomatosis: A pilot study on dietary prevention. Anticancer Res 1998;18:4569-4573.

15 Rosen CA, Woodson GE, Thompson JW, Hengesteg AP, Bradlow HL. Preliminary results of the use of indole-3-carbinol for recurrent respiratory papillomatosis. Otolaryngology--head and neck surgery : official journal of American Academy of Otolaryngology-Head and Neck Surgery 1998;118:810-815. 
16 Thorley-Lawson DA, Allday MJ. The curious case of the tumour virus: 50 years of burkitt's lymphoma. Nature reviews Microbiology 2008;6:913-924.

17 Yustein JT, Dang CV. Biology and treatment of burkitt's lymphoma. Curr Opin Hematol 2007;14:375-381.

18 Jaffe ES, Pittaluga S. Aggressive b-cell lymphomas: A review of new and old entities in the who classification. Hematology / the Education Program of the American Society of Hematology American Society of Hematology 2011;2011:506-514.

19 Magrath I. Lessons from clinical trials in african burkitt lymphoma. Current opinion in oncology 2009;21:462-468.

20 Perez-Chacon G, Llobet D, Pardo C, Pindado J, Choi Y, Reed JC, Zapata JM. Tnfr-associated factor 2 deficiency in b lymphocytes predisposes to chronic lymphocytic leukemia/small lymphocytic lymphoma in mice. J Immunol 2012;189:1053-1061.

21 Kelly GL, Milner AE, Baldwin GS, Bell Al, Rickinson AB. Three restricted forms of epstein-barr virus latency counteracting apoptosis in c-myc-expressing burkitt lymphoma cells. Proc Natl Acad Sci U S A 2006;103:14935-14940.

22 Saha A, Robertson ES. Epstein-barr virus-associated b-cell lymphomas: Pathogenesis and clinical outcomes. Clin Cancer Res 2011;17:3056-3063.

23 Scully R, Xie A. Double strand break repair functions of histone h2ax. Mutat Res 2013;750:5-

14.

24 Redon CE, Weyemi U, Parekh PR, Huang D, Burrell AS, Bonner WM. Gamma-h2ax and other histone post-translational modifications in the clinic. Biochim Biophys Acta 2012;1819:743-756.

25 Wen W, Zhu F, Zhang J, Keum YS, Zykova T, Yao K, Peng C, Zheng D, Cho YY, Ma WY, Bode AM, Dong Z. Mst1 promotes apoptosis through phosphorylation of histone h2ax. J Biol Chem 2010;285:39108-39116.

26 Zhang YJ, Lu CR, Cao Y, Luo Y, Bao RF, Yan S, Xue M, Zhu F, Wang Z, Duan LN. Imatinib induces $\mathrm{h} 2 \mathrm{ax}$ phosphorylation and apoptosis in chronic myelogenous leukemia cells in vitro via caspase-3/mst1 pathway. Acta pharmacologica Sinica 2012;33:551-557.

27 Moiseeva EP, Heukers R, Manson MM. Egfr and src are involved in indole-3-carbinolinduced death and cell cycle arrest of human breast cancer cells. Carcinogenesis 2007;28:435-445.

28 Ricci MS, Jin Z, Dews M, Yu D, Thomas-Tikhonenko A, Dicker DT, El-Deiry WS. Direct repression of flip expression by c-myc is a major determinant of trail sensitivity. Mol Cell Biol 2004;24:8541-8555.

29 Molina-Privado I, Rodriguez-Martinez M, Rebollo P, Martin-Perez D, Artiga MJ, Menarguez J, Flemington EK, Piris MA, Campanero MR. E2f1 expression is deregulated and plays an oncogenic role in sporadic burkitt's lymphoma. Cancer Res 2009;69:4052-4058.

30 Molina-Privado I, Jimenez PR, Montes-Moreno S, Chiodo Y, Rodriguez-Martinez M, Sanchez-Verde L, Iglesias T, Piris MA, Campanero MR. E2f4 plays a key role in burkitt lymphoma tumorigenesis. Leukemia 2012;26:2277-2285.

31 Bell A, Rickinson AB. Epstein-barr virus, the tcl-1 oncogene and burkitt's lymphoma. Trends in microbiology 2003;11:495-497.

32 De Falco G, Leucci E, Lenze D, Piccaluga PP, Claudio PP, Onnis A, Cerino G, Nyagol J, Mwanda W, Bellan C, Hummel M, Pileri S, Tosi P, Stein H, Giordano A, Leoncini L. Gene-expression analysis identifies novel rb/2/p130 target genes in endemic burkitt lymphoma cell lines and primary tumors. Blood 2007;110:1301-1307.

33 Frappier L. Contributions of epstein-barr nuclear antigen 1 (ebna1) to cell immortalization and survival. Viruses 2012;4:1537-1547.

34 Coppotelli G, Mughal N, Callegari S, Sompallae R, Caja L, Luijsterburg MS, Dantuma NP, Moustakas A, Masucci MG. The epstein-barr virus nuclear antigen-1 reprograms transcription by mimicry of high mobility group a proteins. Nucleic Acids Res 2013;41:2950-2962. 
35 Keller U, Nilsson JA, Maclean KH, Old JB, Cleveland JL. Nfkb 1 is dispensable for mycinduced lymphomagenesis. Oncogene 2005;24:6231-6240.

36 McNaughton SA, Marks GC. Development of a food composition database for the estimation of dietary intakes of glucosinolates, the biologically active constituents of cruciferous vegetables. The British journal of nutrition 2003;90:687-697.

37 Bradlow HL. Review. Indole-3-carbinol as a chemoprotective agent in breast and prostate cancer. In Vivo 2008;22:441-445.

38 Bradlow HL, Zeligs MA. Diindolylmethane (dim) spontaneously forms from indole-3-carbinol (i3c) during cell culture experiments. In Vivo 2010;24:387-391.

39 Gromminger S, Mautner J, Bornkamm GW. Burkitt lymphoma: The role of epstein-barr virus revisited. Br J Haematol 2012;156:719-729.

40 Castillo JJ, Beltran BE, Miranda RN, Paydas S, Winer ES, Butera JN. Epstein-barr viruspositive diffuse large b-cell lymphoma of the elderly: What we know so far. Oncologist 2011;16:8796.

41 Bornkamm GW. Epstein-barr virus and its role in the pathogenesis of burkitt's lymphoma: An unresolved issue. Semin Cancer Biol 2009;19:351-365.

42 Polack A, Hortnagel K, Pajic A, Christoph B, Baier B, Falk M, Mautner J, Geltinger C, Bornkamm GW, Kempkes B. C-myc activation renders proliferation of epstein-barr virus (ebv)transformed cells independent of ebv nuclear antigen 2 and latent membrane protein 1 . Proc Natl Acad Sci U S A 1996;93:10411-10416.

43 Pajic A, Staege MS, Dudziak D, Schuhmacher M, Spitkovsky D, Eissner G, Brielmeier M, Polack A, Bornkamm GW. Antagonistic effects of c-myc and epstein-barr virus latent genes on the phenotype of human b cells. Int J Cancer 2001;93:810-816.

44 Boxer LM, Dang CV. Translocations involving c-myc and c-myc function. Oncogene 2001;20:5595-5610.

45 Chang DW, Xing Z, Pan Y, Algeciras-Schimnich A, Barnhart BC, Yaish-Ohad S, Peter ME, Yang X. C-flip(I) is a dual function regulator for caspase-8 activation and cd95-mediated apoptosis. EMBO J 2002;21:3704-3714.

46 Micheau O, Thome M, Schneider P, Holler N, Tschopp J, Nicholson DW, Briand C, Grutter MG. The long form of flip is an activator of caspase-8 at the fas death-inducing signaling complex. J Biol Chem 2002;277:45162-45171.

47 Oberst A, Dillon CP, Weinlich R, McCormick LL, Fitzgerald P, Pop C, Hakem R, Salvesen GS, Green DR. Catalytic activity of the caspase-8-flip(I) complex inhibits ripk3-dependent necrosis. Nature 2011;471:363-367.

48 Pop C, Oberst A, Drag M, Van Raam BJ, Riedl SJ, Green DR, Salvesen GS. Flip(I) induces caspase 8 activity in the absence of interdomain caspase 8 cleavage and alters substrate specificity. Biochem J 2011;433:447-457.

49 Dohrman A, Russell JQ, Cuenin S, Fortner K, Tschopp J, Budd RC. Cellular flip long form augments caspase activity and death of $t$ cells through heterodimerization with and activation of caspase-8. J Immunol 2005;175:311-318.

50 Boatright KM, Deis C, Denault JB, Sutherlin DP, Salvesen GS. Activation of caspases-8 and 10 by flip(I). Biochem J 2004;382:651-657. 

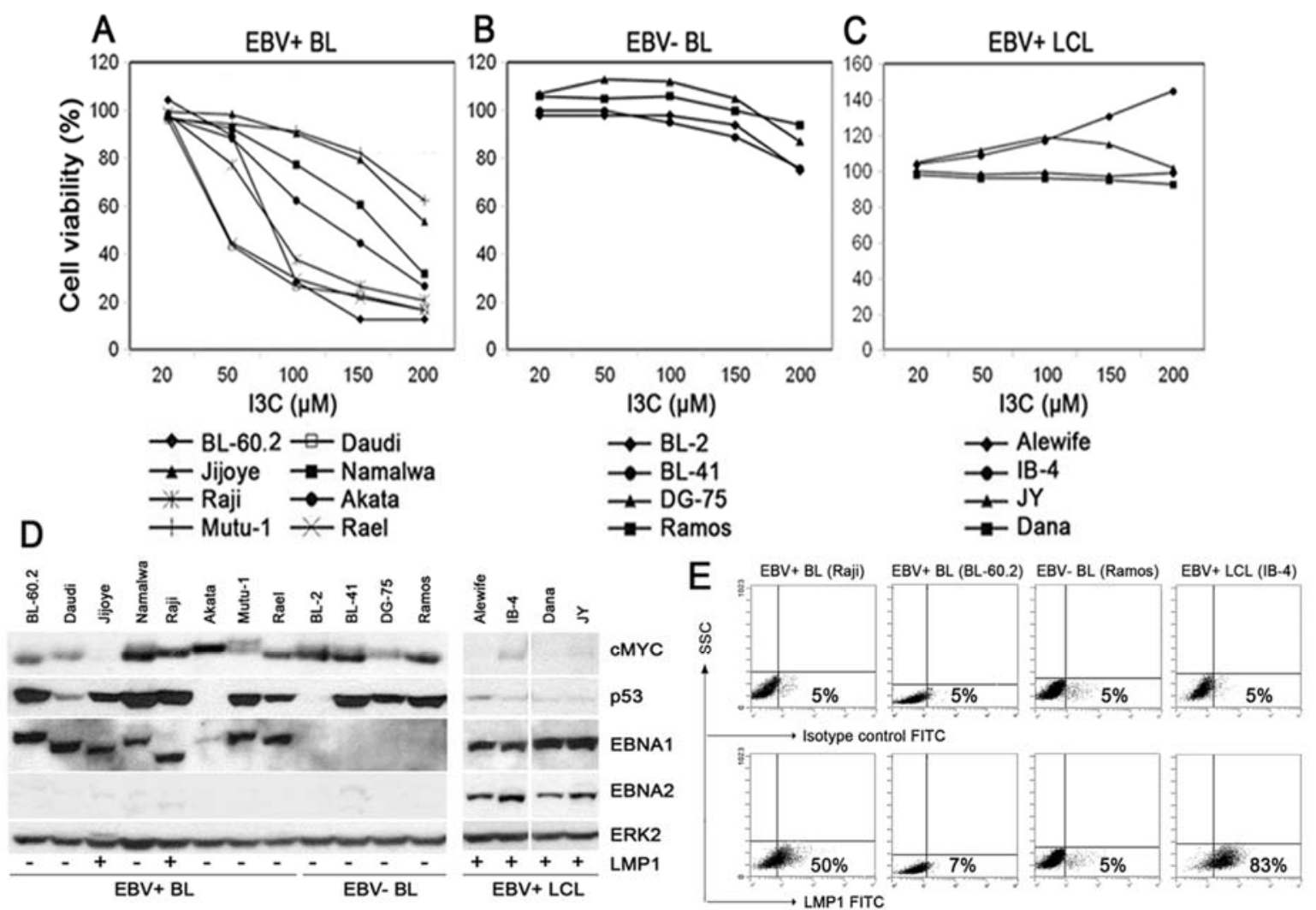

Perez-Chacon et al., Figure $1 \mathbf{2}$ columns 


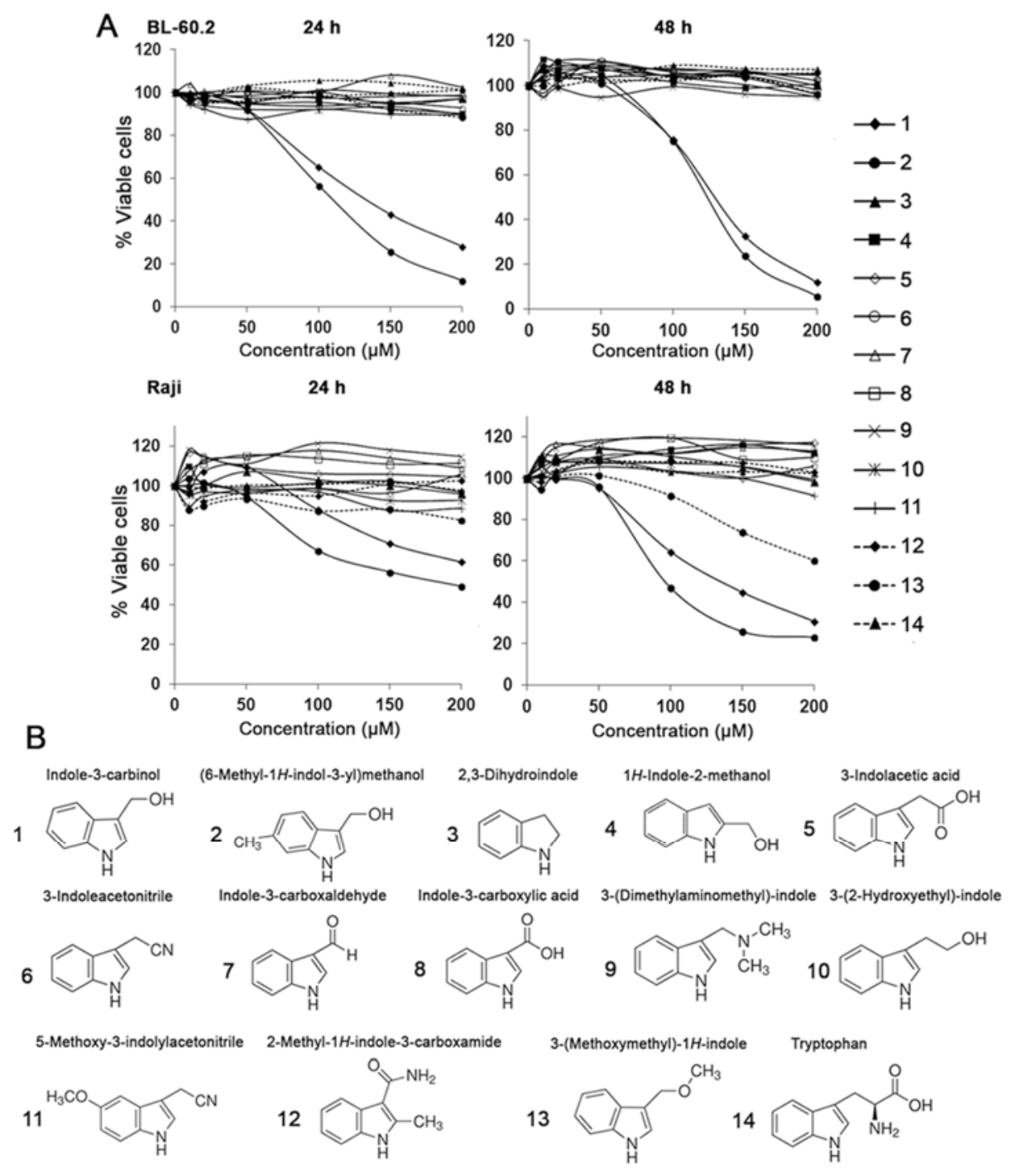

Perez-chacon et al., Figure 2

\section{2 columns}



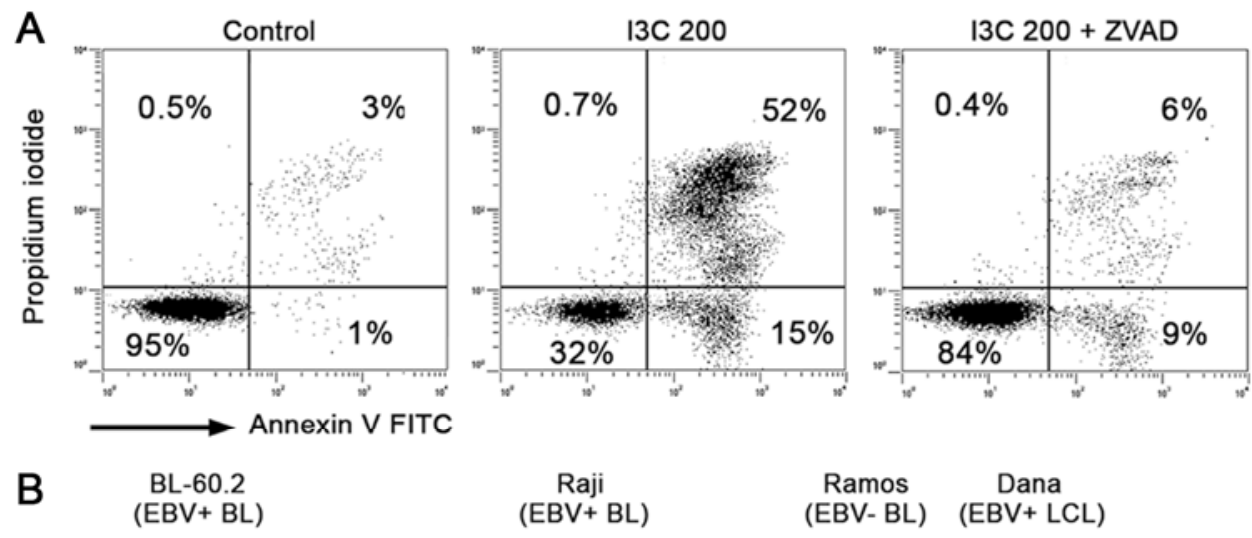

$\begin{array}{cc}\text { Ramos } & \text { Dana } \\ \text { (EBV- BL) } & (E B V+L C L)\end{array}$
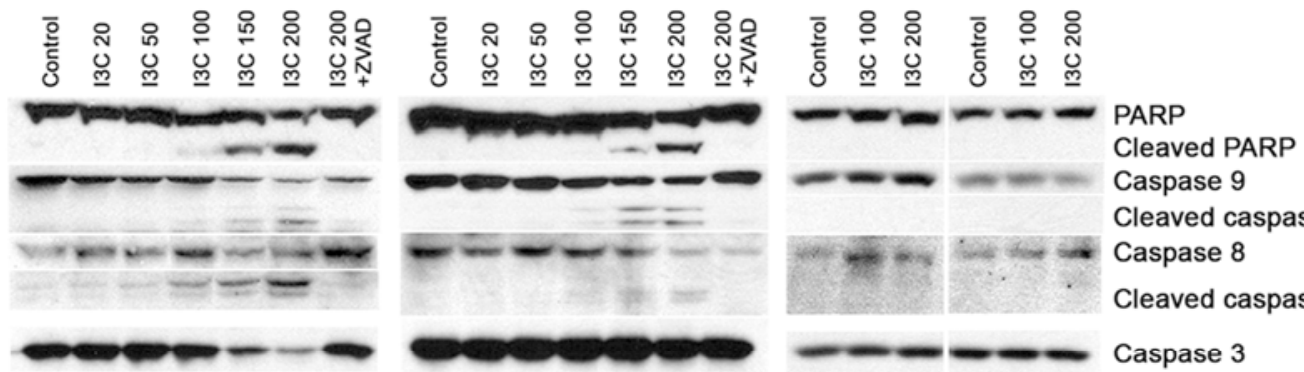

Cleaved PARP

Caspase 9

Cleaved caspase 9

Caspase 8

Cleaved caspase 8
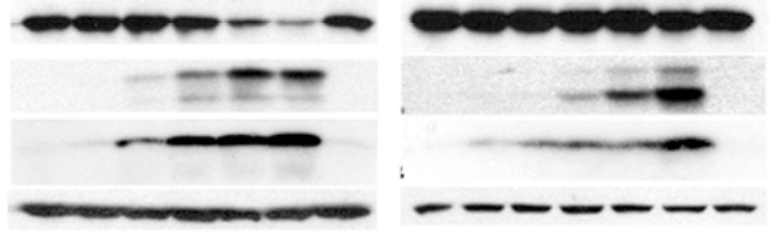

Caspase 3

Cleaved caspase 3

Y-H2A.X

C
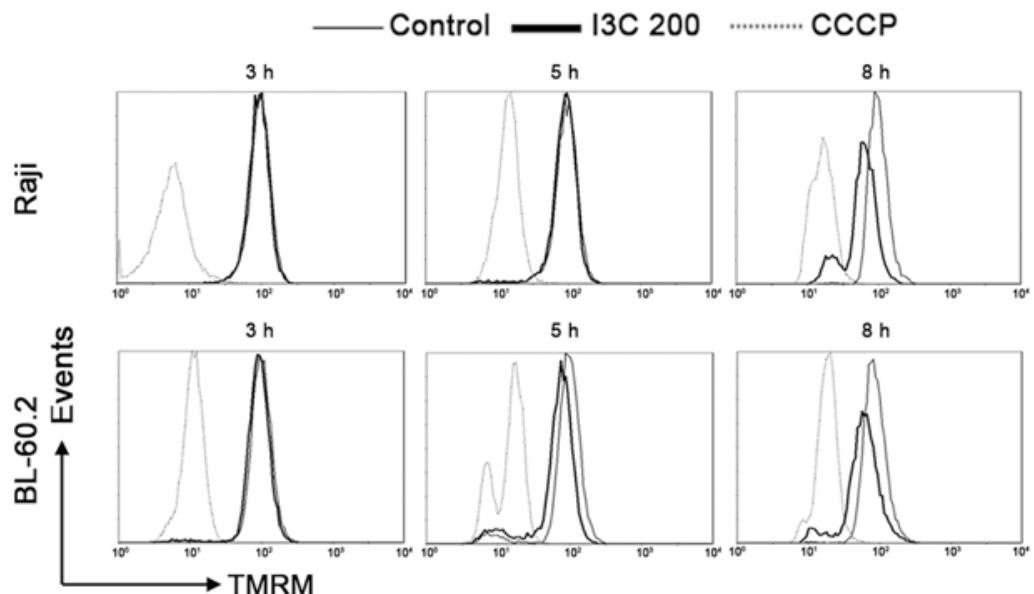

$5 \mathrm{~h}$

$8 \mathrm{~h}$
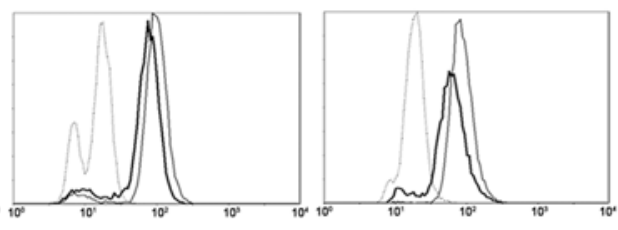

Perez-Chacon et al., Figure 3

2 columns 


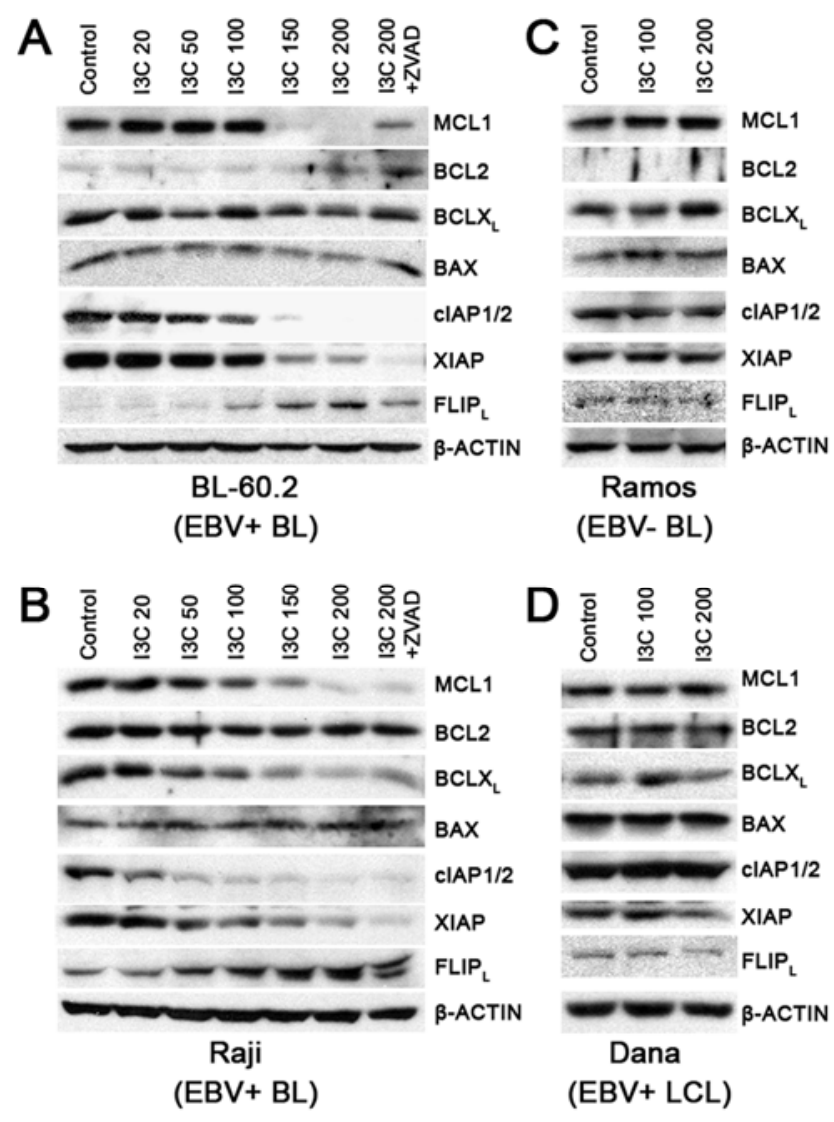

Perez-Chacon et al., Figure $4 \quad 1$ column 


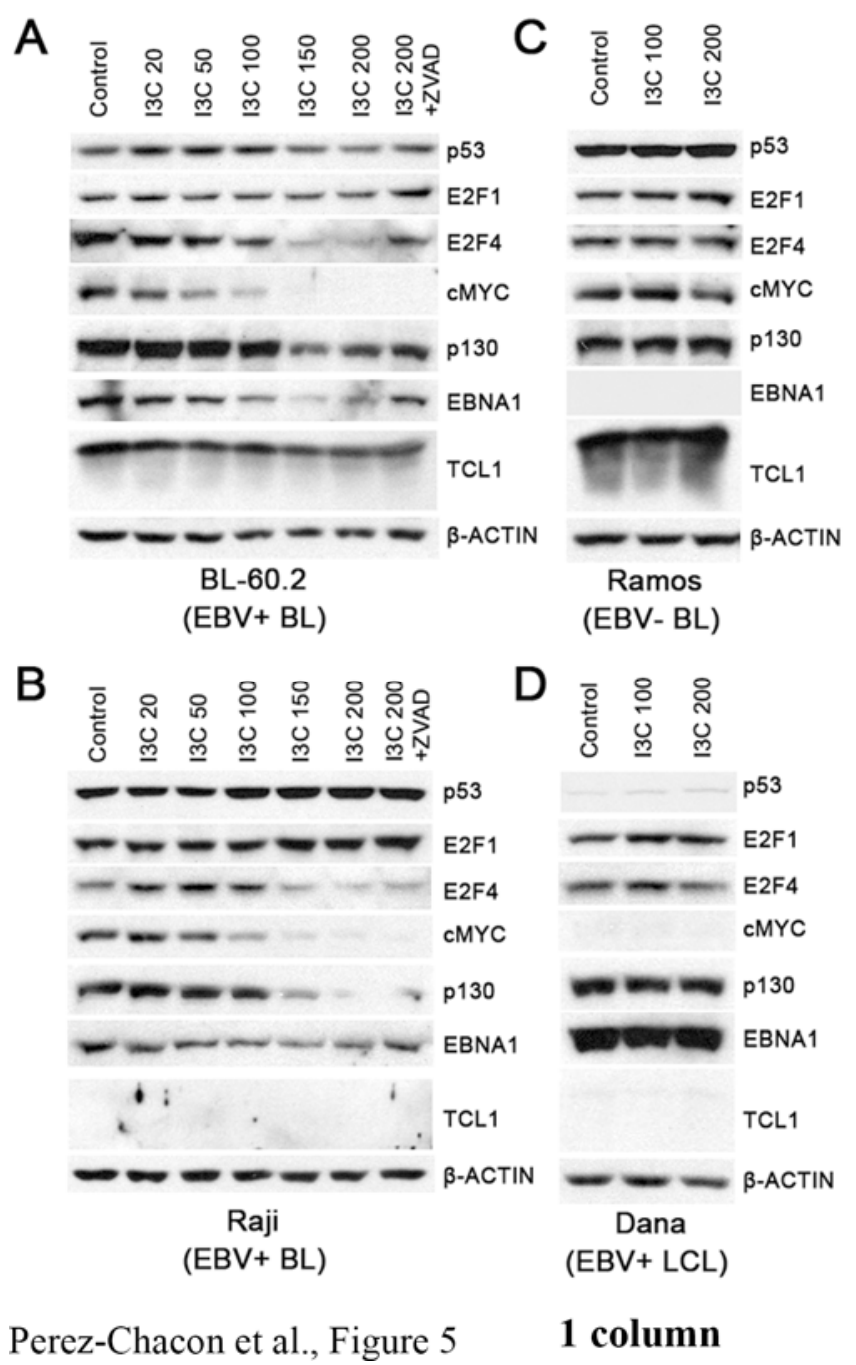



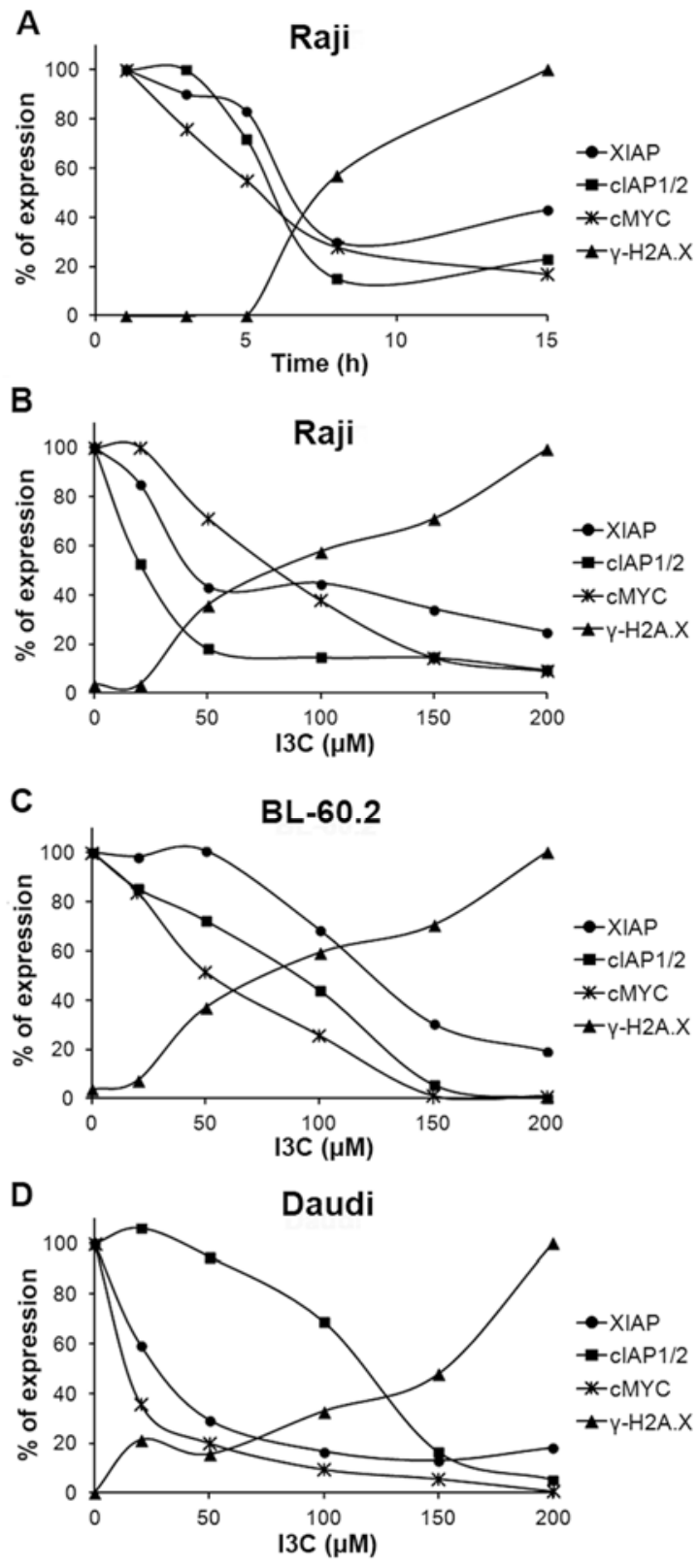

Perez-Chacon et al, Fig 6

1 column 


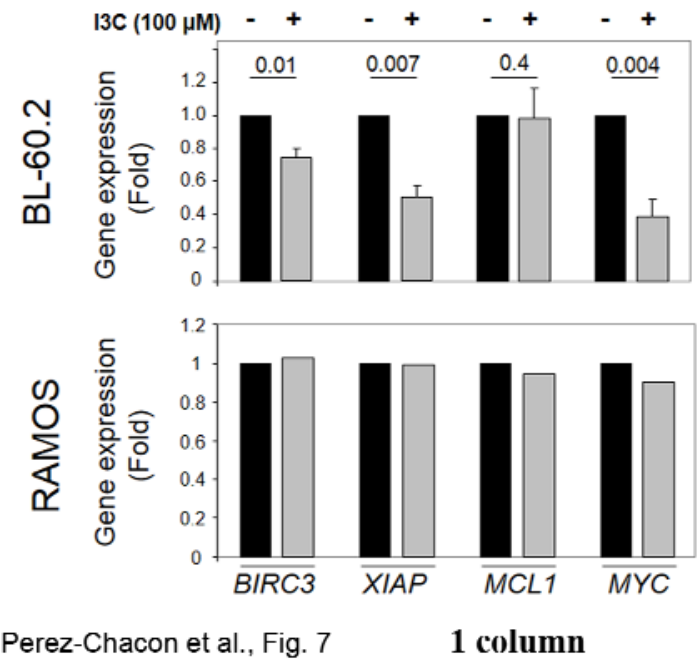




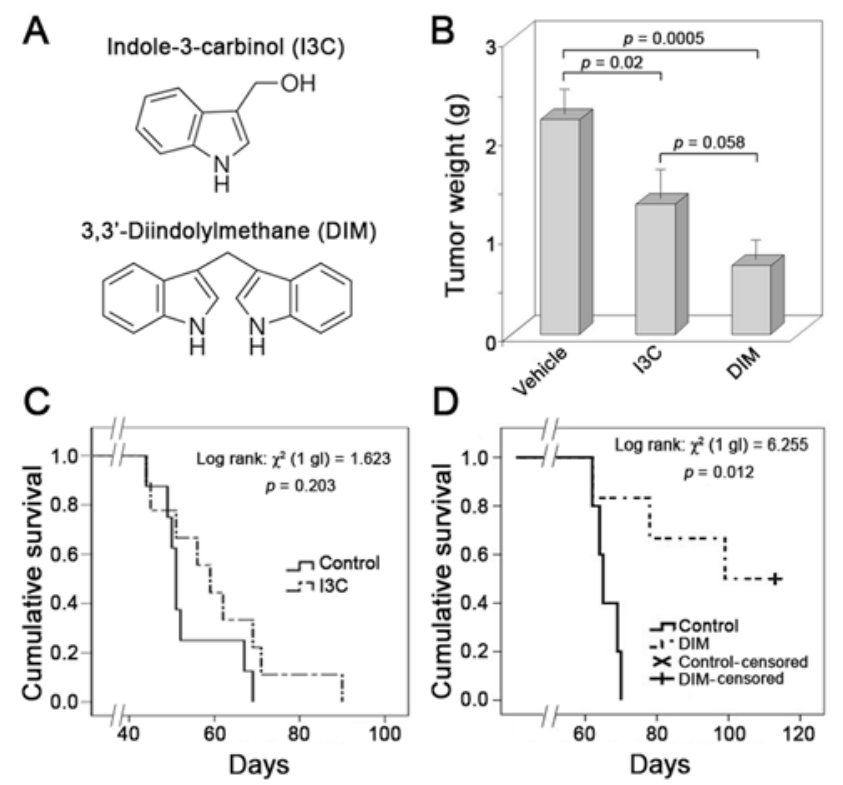

Perez-Chacon et al., Figure $8 \quad \mathbf{1}$ column 


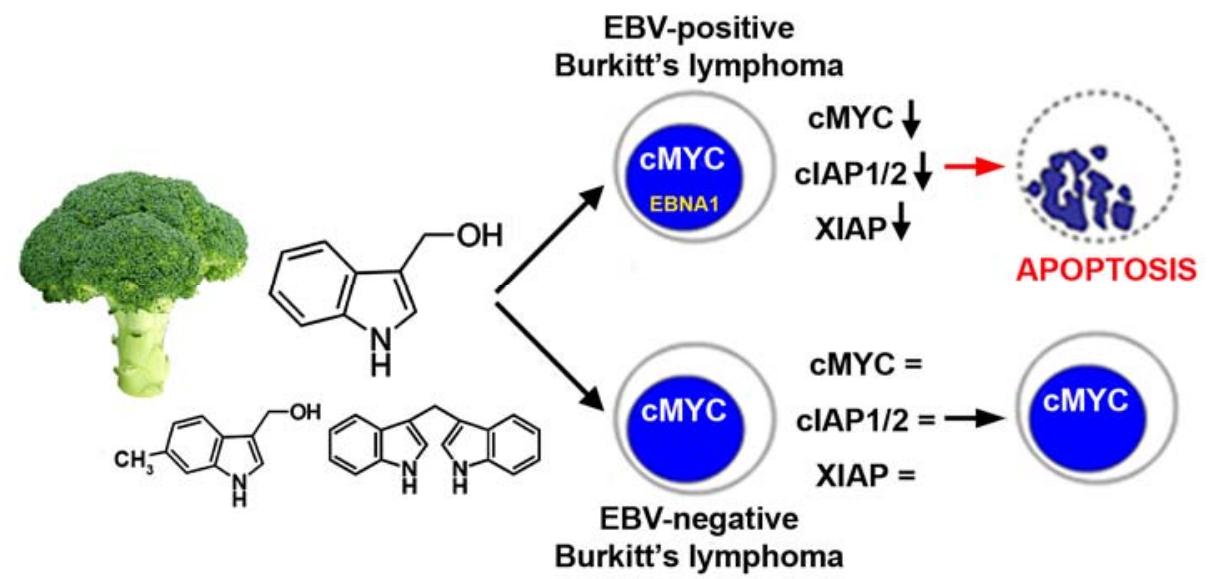

GRAPHICAL ABSTRACT 


\section{Indole-3-carbinol induces cMYC and IAP-family downmodulation and promotes apoptosis of EBV-positive but not EBV-negative Burkitt's lymphoma cell lines}

Gema Perez-Chacon, Cristobal de los Rios and Juan M. Zapata

\section{Supplementary Materials and Methods}

\section{Reagents and antibodies}

The pan-caspase inhibitor Z-Val-Ala-DL-Asp-fluoromethylketone (Z-VAD-fmk) was from Bachem (Bubendrof, Switzerland) and the stock was dissolved in DMSO. Proteasome inhibitor Bortezomib was kindly provided by Millenium Pharmaceuticals (Cambridge, MA). Lactacystin, carbonyl cyanide m-chlorophenylhydrazone (CCCP), 2', 7'-dichlorofluorescein diacetate $\left(\mathrm{H}_{2} \mathrm{DCF}-\mathrm{DA}\right)$, cationic fluorophore tetramethylrhodamine methyl ester (TMRM) and propidium iodide (PI) were from SigmaAldrich. MitoSox ${ }^{\mathrm{TM}}$ red mitochondrial superoxide indicator was from Life Technologies (Grand Island, NY). Antibodies against cMYC (N-262), IкB $\alpha$ (C-21), p65 (C-20), p50 (C19), E2F1 (C-20), E2F4 (C-108), p130 (C-20), ERK2 (C-14), EBNA1, and EBNA2

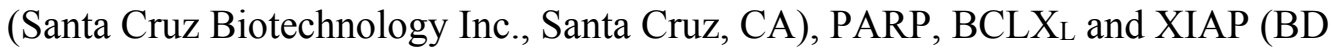
Biosciences, San Jose, CA), CASPASE 3, CASPASE 8, CASPASE 9, p53, p100/p52 NFкB2, TCL1, and $\gamma$-H2A.X (Cell Signaling Technologies, Danvers, MA), cIAP1/2, (R\&D Systems, Abingdon, UK), cMYC (06-340, Millipore, Temecula, CA), and cFLIPL and $\beta$-ACTIN (Sigma-Aldrich) were used for western blot analysis. LMP1 mAb (Acris Antibodies, Herford, Germany), annexin V (BioVision, Milpitas, CA), and goat antimouse-FITC F(ab’)2 (Agilent Technologies, Barcelona, Spain) were used for flow cytometry. Antibodies against human BCL2, MCL1 and BAX have been previously described (1-3). Anti-rabbit and anti-mouse HRP-conjugated secondary antibodies were 
from BioRad Laboratories (Madrid, Spain). Anti-rat and anti-goat HRP-conjugated secondary antibodies were from Santa Cruz Biotechnologies.

Western Blot analysis. Cell lysates were prepared in incomplete Laemmli buffer (0.125M Tris pH 6.8, 4\% SDS and 20\% glycerol) supplemented with phosphatase and protease inhibitors (cOmplete and PhosSTOP tablets, Roche Diagnostics, Mannheim, Germany). Lysates were sonicated and the concentration of total proteins was determined by the bicinchoninic acid method (Pierce, Rockford, IL). Proteins were resolved on 813\% SDS-PAGE gels and transferred to PVDF membrane. After transfer and blocking with $5 \%$ non-fat dry milk or 3\% BSA in TBS/ $0.05 \%$ Tween-20 at room temperature for 2 $\mathrm{h}$, membranes were then probed with the indicated antibodies followed by incubation with HRP-conjugated secondary antibodies in blocking solution. Specific bands were visualized using enhanced chemiluminescence.

LMP1 expression analysis. Intracellular LMP1 expression was determined using a commercial fixation/permeabilization kit (Fitx\&Perm; Invitrogen Life Technologies). Briefly, $10^{6}$ cells were fixed with $100 \mu 1$ Reagent A for 15 min, washed with PBS, and then permeabilized with $100 \mu \mathrm{l}$ Reagent B for $15 \mathrm{~min}$. After washing, cells were incubated with $50 \mu \mathrm{g} / \mathrm{ml} \gamma$-globulin for $10 \mathrm{~min}$ and then with anti-LMP1 1:100 for 20 min. Cells were washed and incubated with goat anti-mouse $\mathrm{F}\left(\mathrm{ab}{ }^{\prime}\right)_{2}$-FITC 1:100 in the presence of $50 \mu \mathrm{g} / \mathrm{ml} \gamma$-globulin for $20 \mathrm{~min}$. Finally, cells were analyzed by flow cytometry using a FC 500 MPL cytofluorimeter and the CXP software version 2.1 (Beckman Coulter Inc., Fullerton, CA). 
Determination of reactive oxygen species (ROS). Cells $\left(10^{6}\right.$ cells $\left./ \mathrm{ml}\right)$ were incubated in the presence of the different reagents at indicated times and then stained with $1 \mu \mathrm{M}$ $\mathrm{H}_{2}$ DCF-DA (cytosolic ROS) or $5 \mu \mathrm{M}$ MitoSox ${ }^{\mathrm{TM}}$ (mitochondrial ROS) for $30 \mathrm{~min}$. Cells were washed with PBS and analyzed by flow cytometry in the FL-1/FITC or the FL-2/PE channel, respectively, as an indicator of ROS production. Serum deprivation was used as a positive control.

Cell cycle analysis. Cells $\left(10^{6}\right.$ cells $\left./ \mathrm{ml}\right)$ were cultured in the presence or in the absence of $200 \mu \mathrm{M}$ I3C. After indicated times, $2 \times 10^{6}$ cells were harvested and centrifugated for 5 min at $200 \mathrm{~g}$, then cells were resuspended in $1.5 \mathrm{ml}$ of PBS at $4{ }^{\circ} \mathrm{C}$ and $3.5 \mathrm{ml}$ of ice-cold $100 \%$ ethanol were added drop-wise while gentle vortexing. Cells were incubated for 45 min at $4{ }^{\circ} \mathrm{C}$ and then overnight at $-20^{\circ} \mathrm{C}$. Fixed cells were centrifugated for $10 \mathrm{~min}$ at 200 $\mathrm{g}$, resuspended in $2 \mathrm{ml}$ of PBS and centrifugated for $8 \mathrm{~min}$ at $200 \mathrm{~g}$, repeating this process twice. Cell pellets were resuspended in $500 \mu \mathrm{l}$ of PI solution (PBS containing $15 \mu \mathrm{g} / \mathrm{ml}$ of PI and $15 \mu \mathrm{g} / \mathrm{ml}$ of RNAse) and incubated for $15 \mathrm{~min}$ at room temperature in the dark. Finally, cells were analyzed by flow cytometry using the ModFit LT software (Verity Software House, Topsham, ME).

Subcellular fractionation. Raji cells $\left(10^{7}\right.$ cells $)$ were resuspended in $150 \mu$ lysis buffer (0.3 M sucrose, $100 \mathrm{mM} \mathrm{KCl,} 10 \mathrm{mM}$ Hepes pH 7.4, $1.5 \mathrm{mM} \mathrm{MgCl}_{2}, 0.5 \mathrm{mM}$ DTT, 0.3\% NP-40, and protease inhibitor cocktail) and incubated on ice for 2 min. Cell lysis was verified by phase-contrast microscopy, Then, lysates were centrifugated for 5 min at 2000 $\mathrm{g}$ to pellet nuclei, and supernatant (cytoplasm) and pellet (nuclei) were collected. The supernatant was centrifugated for $10 \mathrm{~min}$ at $4000 \mathrm{~g}$ to remove residual nuclei. The nuclear pellet was resuspended in lysis buffer and centrifugated for $5 \mathrm{~min}$ at $2000 \mathrm{~g}$ to remove 
residual cytosolic components. Then, nuclei were resuspended in $150 \mu 1$ Laemmli buffer, to normalize cytosolic and nuclear fractions for cell equivalents, and sonicated.

Immunohistochemistry. Tissues and organs from transgenic mice were fixed in $10 \%$ formalin, embedded in paraffin, and tissue sections $(5 \mu \mathrm{m})$ were stained with hematoxylin and eosin (H\&E) and with anti-cMYC polyclonal antibody (Millipore). For mmunohistochemistry, color was developed using a diaminobenzidine-based detection method (Vector Laboratories, Burlingame, CA), and sections were then counterstained with hematoxylin, dehydrated, and mounted in DPX (Fluka).

\section{Supplementary Bibliography}

1. Krajewska M, Krajewski S, Young M, et al. Expression of apoptosis-regulatory proteins Bcl-2, Bax and caspase-3 in non-Hodgkin's lymphomas: An ECOG study (E6491). Blood 1997;90(Suppl.1):76a.

2. Krajewski S, Blomvqvist C, Franssila K, et al. Reduced expression of proapoptotic gene Bax is associated with poor response rates to combination chemotherapy and shorter survival in women with metastatic breast adenocarcinoma. Cancer Res 1995;55:4471-8.

3. Krajewski S, Bodrug S, Gascoyne R, Berean K, Krajewska M, Reed JC. Immunohistochemical analysis of $\mathrm{Mcl}-1$ and $\mathrm{Bcl}-2$ proteins in normal and neoplastic lymph nodes. Am J Pathol 1994;145:515-25. 
Supplementary Table T1. Microsatellite analysis. Cell lines used in this study were subjected to microsatellite analysis for identity confirmation and to rule out possible contamination with other cell lines. Burkitt's lymphoma cell lines Daudi, Jijoye, Namalwa, Raji, BL-2, BL-41, DG-75 and Ramos were analyzed using the StemElite System from Promega, following the manufacturer's instructions. Analyses were performed in an ABI3130XL genetic analyzer and analyzed using the Gene Mapper software (Applied Biosystems, Life Technologies). Microsatellite results were verified using published data from DSMZ and ATCC. Of note is that Burkitt's lymphoma cell lines Rael, BL-60.2, Mutu-1 and Akata, and EBV-infected lymphoblastoid cell lines Alewife, Dana, JY and IB-4 were not included in these analyses since no microsatellite information on these cell lines is found in DSMZ and ATCC databases.

\begin{tabular}{|l|c|c|c|c|c|c|c|c|c|c|c|c|}
\hline & M Musculus & D5S818 & D13S317 & D7S820 & D16S539 & VWA & TH01 & AMEL & TPOX & CSF & Ref. & Coincidence \\
\hline Daudi & Negative & 8.13 & 11.12 & 8.10 & 10.12 & 15.17 & 6.7 & X,Y & 8.11 & 12 & ATCC & $100 \%$ \\
\hline Jijoye & Negative & 12 & 12 & 8.10 & 10.11 & 15.19 & 7.9 & X,Y & 6.8 & 10.11 & ATCC & $100 \%$ \\
\hline Namalwa & Negative & 12.13 & 11.12 & 11 & 9 & 14 & $7,9.3$ & $\mathrm{X}$ & 6.11 & 10.11 & ATCC & $100 \%$ \\
\hline Raji & Negative & 10.13 & 13 & 10 & 8.11 & 16.19 & 6.7 & $\mathrm{X}, \mathrm{Y}$ & 8.13 & 10.12 & ATCC & $100 \%$ \\
\hline BL-2 & Negative & 12 & 11.12 & 8.12 & 12 & 15.16 & 6 & $\mathrm{X}, \mathrm{Y}$ & 8.11 & 11.13 & ATCC & $100 \%$ \\
\hline BL-41 & Negative & 11.13 & 8.11 & 9.11 & 12 & 14.18 & $7,9.3$ & $\mathrm{X}, \mathrm{Y}$ & 7.8 & 10.11 & ATCC & $100 \%$ \\
\hline DG-75 & Negative & 12 & 10.11 & $11.3,12$ & 11.12 & $17,18,19,20$ & 6.7 & $\mathrm{X}, \mathrm{Y}$ & 8.11 & 10.12 & DSMZ & $83 \%$ \\
\hline Ramos & Negative & 7.12 & 13.14 & 11 & 10.13 & 15.16 & $7,9.3$ & $\mathrm{X}$ & 8.9 & 10.11 & ATCC & $100 \%$ \\
\hline
\end{tabular}




\section{Supplementary Table T2}

I3C efficiently reduces cell viability in EBV-positive Burkitt's lymphoma cell lines but it has no effect in EBV-negative Burkitt's lymphoma and EBV-infected lymphoblastoid cell lines viability. Cells $\left(10^{5}\right)$ were incubated in the presence of the indicated concentrations of $\mathrm{I} 3 \mathrm{C}$ and cultured at $37 \mathrm{C}$ in $5 \% \mathrm{CO}_{2}$ atmosphere. Cell viability was determined $24 \mathrm{~h}$ and $48 \mathrm{~h}$ after $\mathrm{I} 3 \mathrm{C}$ addition using the CellTiter $96^{\circ}$ AQueous Assay (Promega Biotech Iberica, Madrid, Spain), following the manufacturer's instructions. Data shows average $+/$ - SD of three independent experiments in which each condition was analyzed in triplicate.

Time (h)

\begin{tabular}{|c|c|c|c|c|c|c|}
\hline \multirow[b]{2}{*}{ I3C ( $(\mu \mathrm{M})$} & \\
\hline & & 20 & 50 & 100 & 150 & 200 \\
\hline \multirow{8}{*}{ EBV+ BL } & BL-60.2 & $94 \pm 6$ & $89 \pm 7$ & $63 \pm 14$ & $43 \pm 16$ & $29 \pm 10$ \\
\hline & Jijoye & $101 \pm 4$ & $100 \pm 4$ & $94 \pm 4$ & $87 \pm 8$ & $75 \pm 7$ \\
\hline & Raji & $98 \pm 3$ & $91 \pm 9$ & $67 \pm 11$ & $53 \pm 13$ & $50 \pm 11$ \\
\hline & Mutu-1 & $96 \pm 4$ & $97 \pm 6$ & $97 \pm 6$ & $93 \pm 4$ & $88 \pm 4$ \\
\hline & Daudi & $93 \pm 2$ & $72 \pm 4$ & $42 \pm 7$ & $37 \pm 8$ & $32 \pm 7$ \\
\hline & Namalwa & $103 \pm 4$ & $99 \pm 5$ & $92 \pm 8$ & $86 \pm 10$ & $62 \pm 17$ \\
\hline & Akata & $97 \pm 4$ & $94 \pm 7$ & $92 \pm 11$ & $88 \pm 17$ & $81 \pm 26$ \\
\hline & Rael & $92 \pm 3$ & $61 \pm 6$ & $20 \pm 1$ & $19 \pm 2$ & $15 \pm 4$ \\
\hline \multirow{4}{*}{ EBV- BL } & BL-2 & $99 \pm 1$ & $98 \pm 1$ & $96 \pm 6$ & $95 \pm 2$ & $91 \pm 6$ \\
\hline & BL-41 & $103 \pm 4$ & $103 \pm 4$ & $103 \pm 5$ & $103 \pm 4$ & $96 \pm 1$ \\
\hline & DG-75 & $107 \pm 5$ & $106 \pm 10$ & $104 \pm 7$ & $106 \pm 8$ & $105 \pm 11$ \\
\hline & Ramos & $102 \pm 1$ & $102 \pm 1$ & $109 \pm 8$ & $110 \pm 9$ & $108 \pm 6$ \\
\hline \multirow{4}{*}{ EBV+ LCL } & Alewife & $102 \pm 1$ & $103 \pm 1$ & $105 \pm 1$ & $105 \pm 6$ & $103 \pm 5$ \\
\hline & IB-4 & $98 \pm 4$ & $98 \pm 1$ & $100 \pm 1$ & $103 \pm 6$ & $102 \pm 7$ \\
\hline & JY & $102 \pm 2$ & $105 \pm 2$ & $106 \pm 3$ & $103 \pm 4$ & $100 \pm 9$ \\
\hline & Dana & $97 \pm 1$ & $97 \pm 1$ & $97 \pm 1$ & $101 \pm 5$ & $102 \pm 3$ \\
\hline
\end{tabular}

$48 \mathrm{~h}$

\begin{tabular}{|c|c|c|c|c|}
\hline \multicolumn{1}{c}{20} & 50 & 100 & 150 & 200 \\
\hline $104 \pm 6$ & $89 \pm 4$ & $28 \pm 6$ & $12 \pm 1$ & $12 \pm 3$ \\
\hline $99 \pm 2$ & $98 \pm 2$ & $90 \pm 6$ & $79 \pm 17$ & $53 \pm 25$ \\
\hline $98 \pm 3$ & $77 \pm 9$ & $37 \pm 9$ & $26 \pm 10$ & $20 \pm 2$ \\
\hline $96 \pm 1$ & $94 \pm 6$ & $91 \pm 8$ & $82 \pm 4$ & $62 \pm 7$ \\
\hline $96 \pm 1$ & $43 \pm 8$ & $26 \pm 15$ & $22 \pm 11$ & $16 \pm 8$ \\
\hline $97 \pm 4$ & $92 \pm 10$ & $77 \pm 17$ & $60 \pm 9$ & $31 \pm 17$ \\
\hline $97 \pm 5$ & $88 \pm 9$ & $62 \pm 27$ & $44 \pm 34$ & $26 \pm 20$ \\
\hline $99 \pm 16$ & $44 \pm 16$ & $29 \pm 1$ & $21 \pm 14$ & $16 \pm 13$ \\
\hline $98 \pm 0$ & $98 \pm 1$ & $98 \pm 1$ & $94 \pm 9$ & $75 \pm 7$ \\
\hline $100 \pm 6$ & $100 \pm 3$ & $95 \pm 4$ & $89 \pm 1$ & $76 \pm 5$ \\
\hline $107 \pm 8$ & $113 \pm 8$ & $112 \pm 6$ & $105 \pm 21$ & $87 \pm 23$ \\
\hline $102 \pm 1$ & $104 \pm 4$ & $105 \pm 6$ & $101 \pm 4$ & $92 \pm 3$ \\
\hline $100 \pm 1$ & $98 \pm 1$ & $99 \pm 4$ & $97 \pm 4$ & $99 \pm 1$ \\
\hline $104 \pm 6$ & $109 \pm 5$ & $117 \pm 2$ & $131 \pm 8$ & $145 \pm 8$ \\
\hline $105 \pm 4$ & $112 \pm 6$ & $119 \pm 6$ & $115 \pm 1$ & $102 \pm 14$ \\
\hline $98 \pm 1$ & $96 \pm 1$ & $96 \pm 2$ & $95 \pm 3$ & $93 \pm 4$ \\
\hline
\end{tabular}




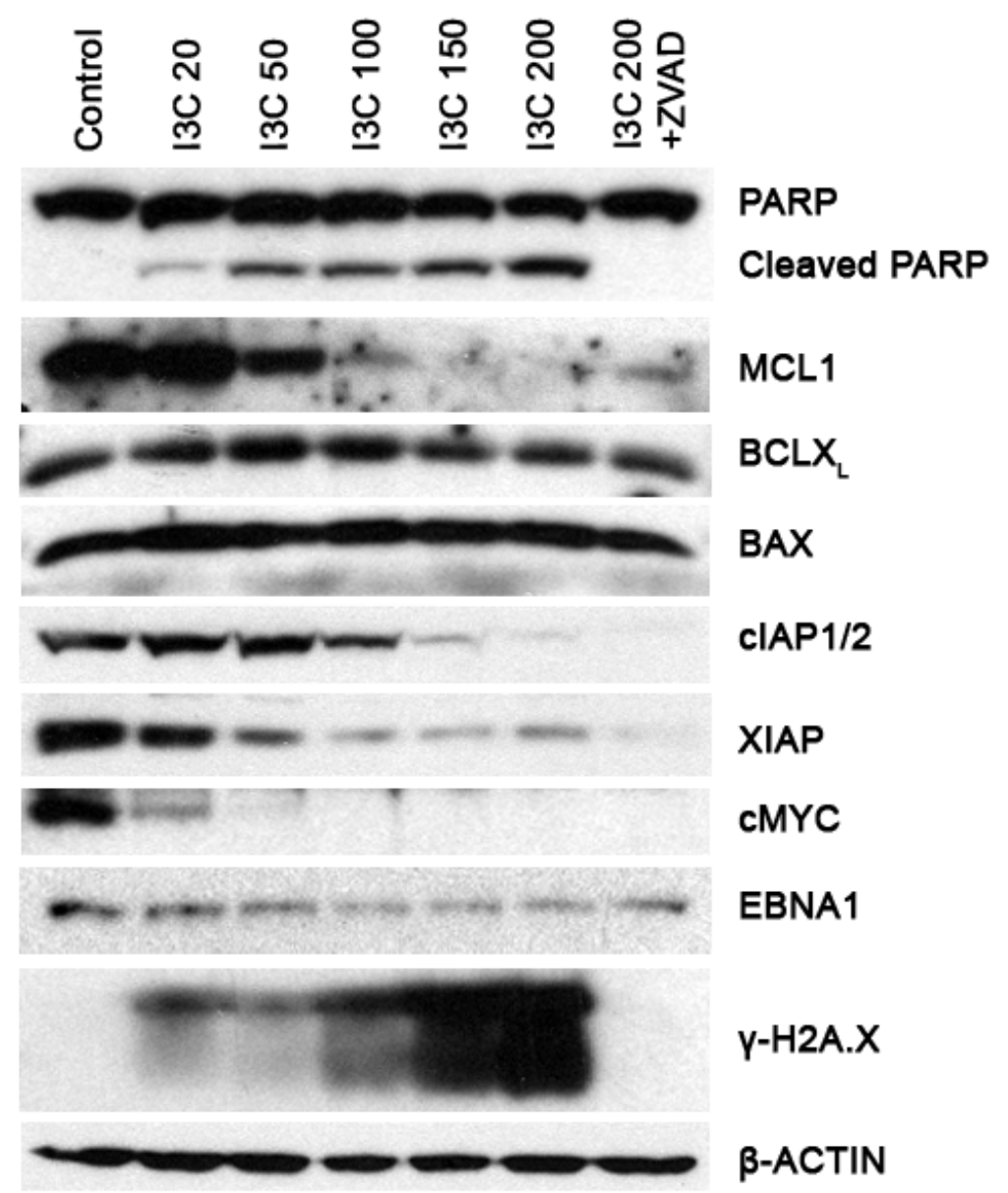

Supplementary Figure S1. Analysis of the effect of I3C on the expression of cMYC, EBNA1 and different proteins implicated in the control of apoptosis in EBV-positive BL Daudi cells. Daudi cells $\left(10^{6}\right.$ cells $\left./ \mathrm{ml}\right)$ were cultured in medium containing vehicle control $(0.02 \%$ ethanol/DMSO) or with increasing doses of I3C (20-200 $\mu \mathrm{M})$. When indicated, 100 $\mu \mathrm{M}$ Z-VAD-fmk (ZVAD) was added. After $24 \mathrm{~h}$ of incubation cells were lysed in Laemmli buffer and sonicated. A total of $12 \mu \mathrm{g}$ of protein from each sample were subjected to $8-13 \%$ SDS-PAGE and immunoblotting with specific antibodies as indicated. $\beta$-ACTIN was used as a loading control. 

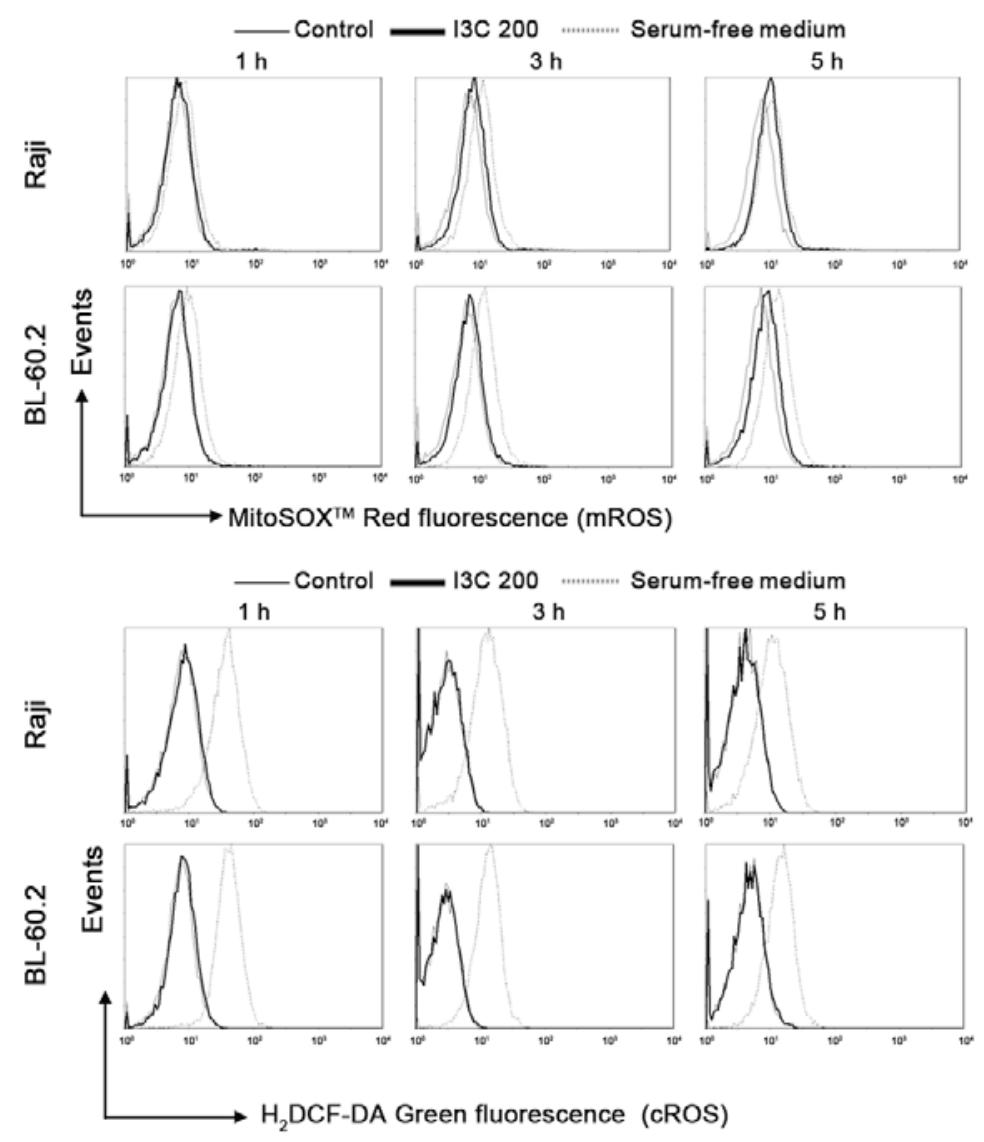

Supplementary Figure S2. I3C does not induce ROS production in EBV-positive Burkitt's lymphoma cell lines. A. I3C does not induce mitochondrial ROS production. BL-60.2 and Raji cells $\left(10^{6}\right.$ cell $\left./ \mathrm{ml}\right)$ were cultured in the presence of vehicle control $(<0.02 \%$ ethanol) or $200 \mu \mathrm{M}$ I3C. At indicated times, cells were harvested and stained with $5 \mu \mathrm{M}$ MitoSox ${ }^{\mathrm{TM}}$ for mitochondrial ROS production measuring (mROS) and analyzed by flow cytometry. Cells cultured in serum-free medium were used as a positive control. B. I3C does not induce cytosolic ROS production. BL-60.2 and Raji cells $\left(10^{6}\right.$ cell $/ \mathrm{ml})$ were cultured in the presence of vehicle control $(<0.02 \%$ ethanol $)$ or $200 \mu \mathrm{M} \mathrm{I3C}$. At indicated times, cells were harvested and stained with $1 \mu \mathrm{M} \mathrm{H} \mathrm{H}_{2} \mathrm{DCF}-\mathrm{DA}$ for cytosolic ROS production measuring (cROS) and analyzed by flow cytometry. Cells cultured in serum-free medium were used as a positive control. 


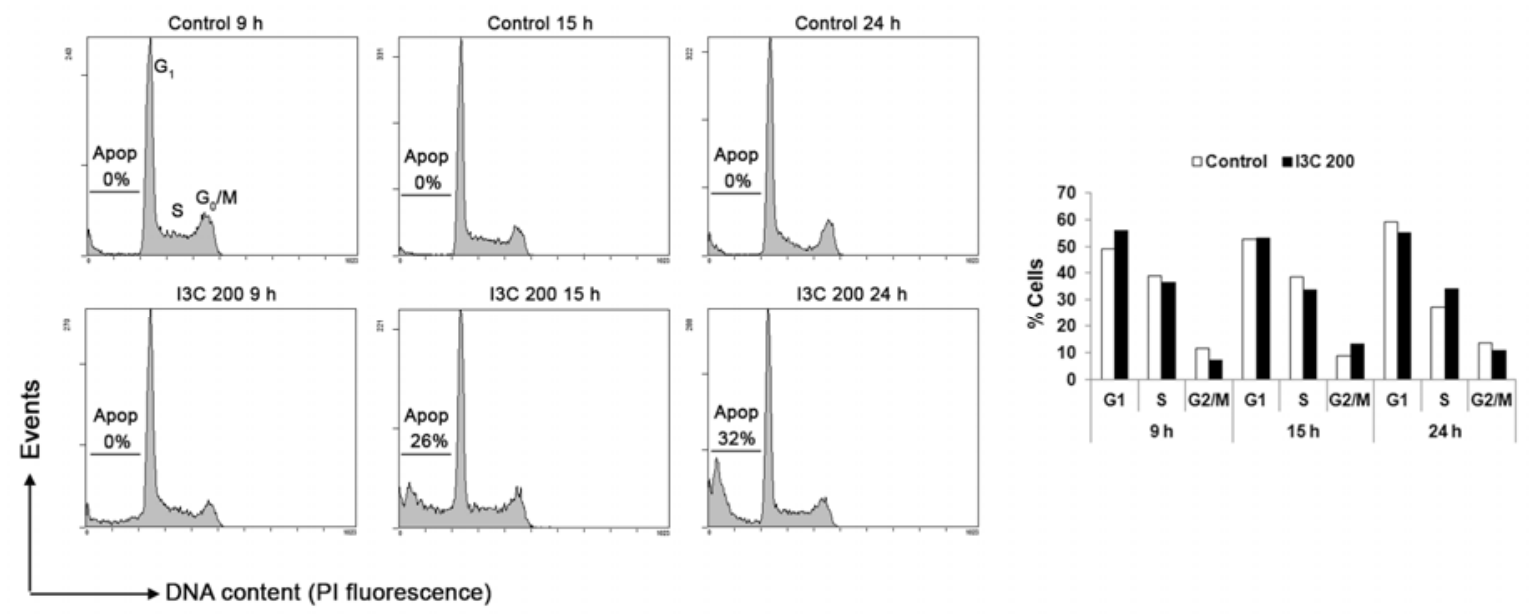

Supplementary Figure S3. I3C does not induce any significant cell cycle alteration in BL-60.2 EBV-positive Burkitt's lymphoma cells. BL-60.2 cells were cultured with vehicle control $(<0.02 \%$ ethanol $)$ o with $200 \mu \mathrm{M} \mathrm{I3C}$ for indicated times. Then, $2 \times 10^{6}$ cells were harvested and effects of $\mathrm{I} 3 \mathrm{C}$ on the cell cycle were determined by flow cytometry of PI-stained nuclei as described in supplementary Materials and methods. (A) A representative histogram of cell cycle at 8,15 and $24 \mathrm{~h}$. (B) The bar graph show the percentage of cells in each phase of cell cycle $\left(\mathrm{G}_{1}, \mathrm{~S}\right.$ and $\left.\mathrm{G}_{2} / \mathrm{M}\right)$, according to the analysis using the ModFit LT software. 


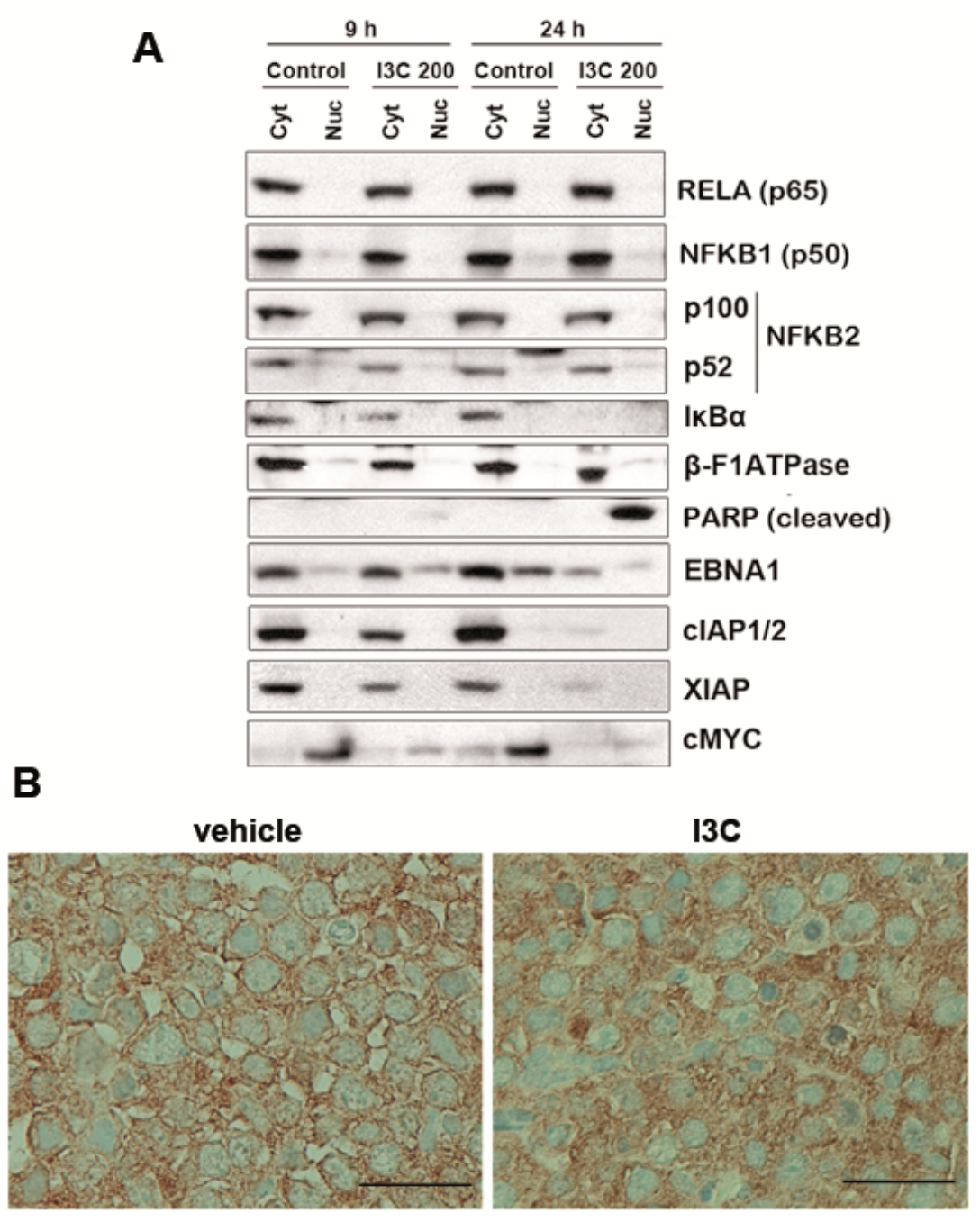

Supplementary Figure S4. I3C does not alter the subcellular localization or processing of NFKB proteins. A. Raji cells were incubated in the presence of vehicle $(0.02 \%$ ethanol) or I3C $(200 \mu \mathrm{M})$. After $9 \mathrm{~h}$ and $24 \mathrm{~h}$ of incubation, cells were harvested, washed with PBS and nuclei and cytoplasm were isolated as described in Materials and methods. Then, a total of $15 \mu \mathrm{g}$ of cytoplasmic protein and the corresponding volume of nuclear protein were subjected to $8 \%$ SDS-PAGE and immunoblotting with specific antibodies as indicated. B. NOD/SCID mice were xenotransplanted with EBV-positive BL Daudi cells and treated either with vehicle or I3C as described in Materials and methods. Mice were euthanized when the mouse treated with vehicle showed symptoms of terminal disease. Figure shows the staining with anti-RELA (p65) ab. Bar: $25 \mu \mathrm{m}$. 

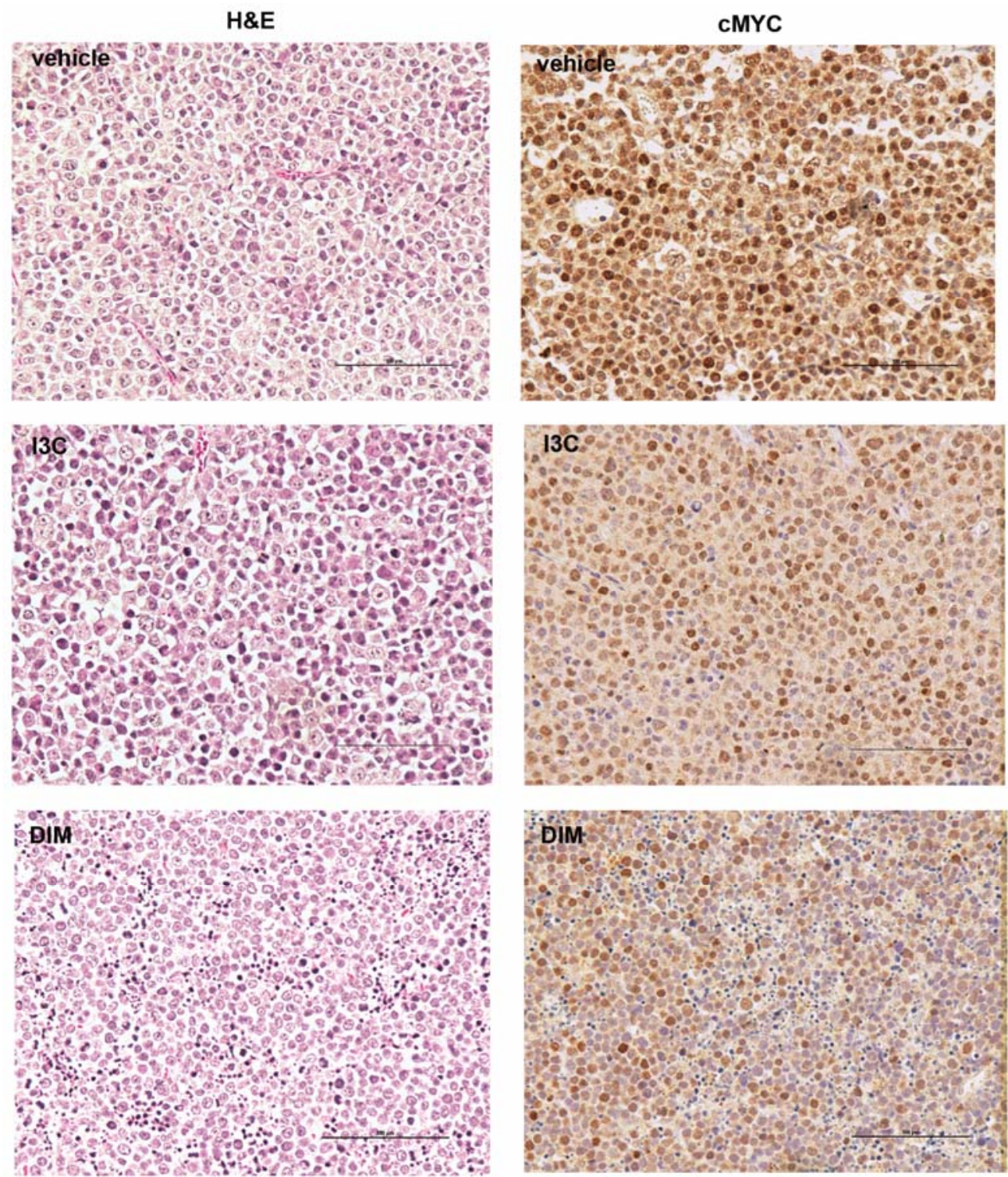

\section{Supplementary Figure S5. Effect of I3C and DIM treatment in cMYC expression in}

Daudi tumors. NOD/SCID mice were xenotransplanted with EBV+ BL Daudi cells and treated either with vehicle (top panels), I3C (central panels) or DIM (bottom panels) as described in Materials and methods. All mice were euthanized when the mouse treated with vehicle showed symptoms of terminal disease. Figure shows the staining with hematoxylin/eosin (left panels) and immunohistochemical staining with anti-cMYC ab (right panels). Bar: $100 \mu \mathrm{m}$ 